\title{
Silver Nanoparticles against Foodborne Bacteria. Effects at Intestinal Level and Health Limitations
}

\author{
Irene Zorraquín-Peña, Carolina Cueva, Begoña Bartolomé ${ }^{\mathbb{D}}$ and M. Victoria Moreno-Arribas *(iD) \\ Institute of Food Science Research (CIAL), CSIC-UAM, C/Nicolás Cabrera 9, Campus de Cantoblanco, \\ 28049 Madrid, Spain; irene.zorraquin@csic.es (I.Z.-P.); carolina.cueva@csic.es (C.C.); b.bartolome@csic.es (B.B.) \\ * Correspondence: victoria.moreno@csic.es; Tel.:+34-91-0017969; Fax: +34-910017905
}

Received: 5 December 2019; Accepted: 13 January 2020; Published: 17 January 2020

\begin{abstract}
Foodborne diseases are one of the factors that endanger the health of consumers, especially in people at risk of exclusion and in developing countries. The continuing search for effective antimicrobials to be used in the food industry has resulted in the emergence of nanotechnology in this area. Silver nanoparticles (Ag-NPs) are the nanomaterial with the best antimicrobial activity and therefore, with great potential of application in food processing and packing. However, possible health effects must be properly addressed to ensure food safety. This review presents a detailed description on the main applications of Ag-NPs as antimicrobial agents for food control, as well as the current legislation concerning these materials. Current knowledge about the impact of the dietary exposure to Ag-NPs in human health with special emphasis on the changes that nanoparticles undergo after passing through the gastrointestinal tract and how they alter the oral and gut microbiota, is also summarized. It is concluded that given their potential and wide properties against foodborne pathogens, research in Ag-NPs is of great interest but is not exempt from difficulties that must be resolved in order to certify the safety of their use.
\end{abstract}

Keywords: foodborne antimicrobials; silver nanoparticles; gut and microbiota; health

\section{Introduction}

It is estimated that there are 600 million cases of foodborne illnesses and 420,000 deaths annually worldwide. Unsafe foods are a risk to human health and countries' economy and mainly affect people at risk of exclusion, migrants and population under conflicts. The majority of foodborne diseases are related to pathogenic bacteria belonging to the genera Salmonella, Listeria, Escherichia, Clostridium and Campylobacter. Microbial contamination of food can occur at different stages of the process, such as harvesting, slaughtering, processing and distribution ("farm to fork") and can be caused by environmental contamination, such as water, soil or air [1]. The most common symptoms of foodborne diseases are gastrointestinal, such as diarrhea, but other consequences may be kidney and liver failure, brain and neural disorders, reactive arthritis and others. These diseases can be more severe in children, pregnant women, the elderly and those with a weakened immune system [2]. Traditional techniques such as salting, drying, freezing or fermentation are applied to extend the shelf life of food products, but there may be risk of recontamination. Therefore, there is a continuous need for antimicrobial agents that act in both food processing (preservation) and packaging (safety) stages [3].

In recent years, nanotechnology has experienced a noticeable rise in its applications, from agri-food to biotechnology, going through the engineering, cosmetic and textile industry. It can be considered a technological revolution [4]. Focusing on the field of food and health, nanotechnology is used in drug delivery system and nutrient release systems (nanoencapsulation), increasing the rate of recognition of disease symptoms and providing rapid treatments. It can also be applied to crops in the form of 
fertilizers and nanoscale additives or create nanoscale sensors to detect chemical, viral or bacterial contamination. In the case of food processing, it is a still emerging but promising technology [5].

Nanomaterials can be natural, accidental or manufactured and can be constituted by loose particles, aggregates or agglomerate in the form of nanoparticles, nanotubes, nanowires, nanofibers, and others. Of these, nanoparticles (NPs), wherein $50 \%$ or more of them in the numerical granulometry have one or more of the external dimensions between 1 and 100 nanometers, are possibly the most studied and the ones having more variety of sizes and shapes, which results in a large number of technological applications [6-8].

NPs are generally classified into organic and inorganic. Organic NPs incorporate carbon, whereas inorganic NPs incorporate metallic $(\mathrm{Ag}, \mathrm{Au}, \mathrm{Cu})$, magnetic $(\mathrm{Co}, \mathrm{Fe}, \mathrm{Ni})$, and/or semi-conductor components ( $\mathrm{ZnO}, \mathrm{ZnS}, \mathrm{CdS}$ ) [9]. Focusing our interest on silver nanoparticles (Ag-NPs), these have been widely used in medicine and biotechnology fields, due to their properties as antimicrobials. In this sense, numerous research studies have confirmed the effectiveness of Ag-NPs to inhibit the growth of pathogenic bacteria such as Staphylococcus aureus, Streptococcus mutans, Streptococcus pyogenes, Escherichia coli and Proteus vulgaris [10-12]. Interestingly, this activity has been also demonstrated using Ag-NPs obtained by 'biological methods' which are considered a great tool to reduce the negative effects associated with traditional nanoparticle synthesis commonly used in the laboratory [13]. In particular, two recent studies have shown the antimicrobial activity of Ag-NPs from apple pomace and from exopolysaccharides isolated from green microalgae against $E$. coli and S. aureus $[14,15]$.

Shape, size, surface and charge are highlighted as the factors that influence the antimicrobial properties of Ag-NPs (Figure 1). Regarding shape (i.e., triangular, decahedron, spherical, cubic, platelet, among others), the spherical and the triangular forms seem to lead to higher antimicrobial activity [16-18]. Size is one of the most important factors when synthesizing nanoparticles, 1 to $30 \mathrm{~nm}$ being the most widely used range. Many studies have shown the size-dependent antibacterial activity of Ag-NPs [19-22]. Concerning the nanoparticle surface, it may be modified through the addition of coating agents, such as polymers (chitosan, polyethyleneimine, polyethylene glycol, polygamma glutamic acid), proteins (milk casein, bovine serum albumin, human serum albumin), antioxidants (glutathione) and/or polyvalent anion salts. Finally, the charge of the Ag-NPs determines their interaction with biological environments and its cellular uptake, which leads to a modulation of its antibacterial activity. Moreover, the antimicrobial activity of silver nanoparticles is bacteria strain- and cell wall structure-dependent [23].

The mechanisms of action by which Ag-NPs exert their antimicrobial effects are not completely clear, but two main hypothesis have been proposed: (i) a direct interaction of the nanoparticle with the cell membrane, and (ii) the release of ionic silver [24]. In the first hypothesis, the Ag-NPs would be adhered to the cell membrane via electrostatic attractions between the positive charges of the nanoparticles and the negative charges of the cells [25] or via the interaction of the nanoparticles into the sulfur and phosphorylated proteins present in the cell wall [26]. In any case, the interaction of the Ag-NPs with the cell membrane would produce its partial dissolution (Figure 1). In the second hypothesis, the Ag-NPs would enter into the cell and lead to a release of silver ions and the subsequent increase of reactive oxygen species (ROS) that would damage the enzymes involved in the cellular oxidation-reduction respiratory process and be finally responsible for cell death [16] (Figure 1). The two hypotheses could occur together as it has been showed that after interaction of the nanoparticle with the cell membrane, an internalization step takes place. In turn, this process can be affected by the nanoparticle charge [27]. Despite the antimicrobial effectiveness, some bacterial resistance against silver nanoparticles has been reported. Mechanisms such as negative regulation of porins, chromosomal resistance genes or plasmids with resistance genes have been proposed. However, this is still a field under study and more information to clarify this point at the frame of the food industry is clearly needed $[24,28]$. 


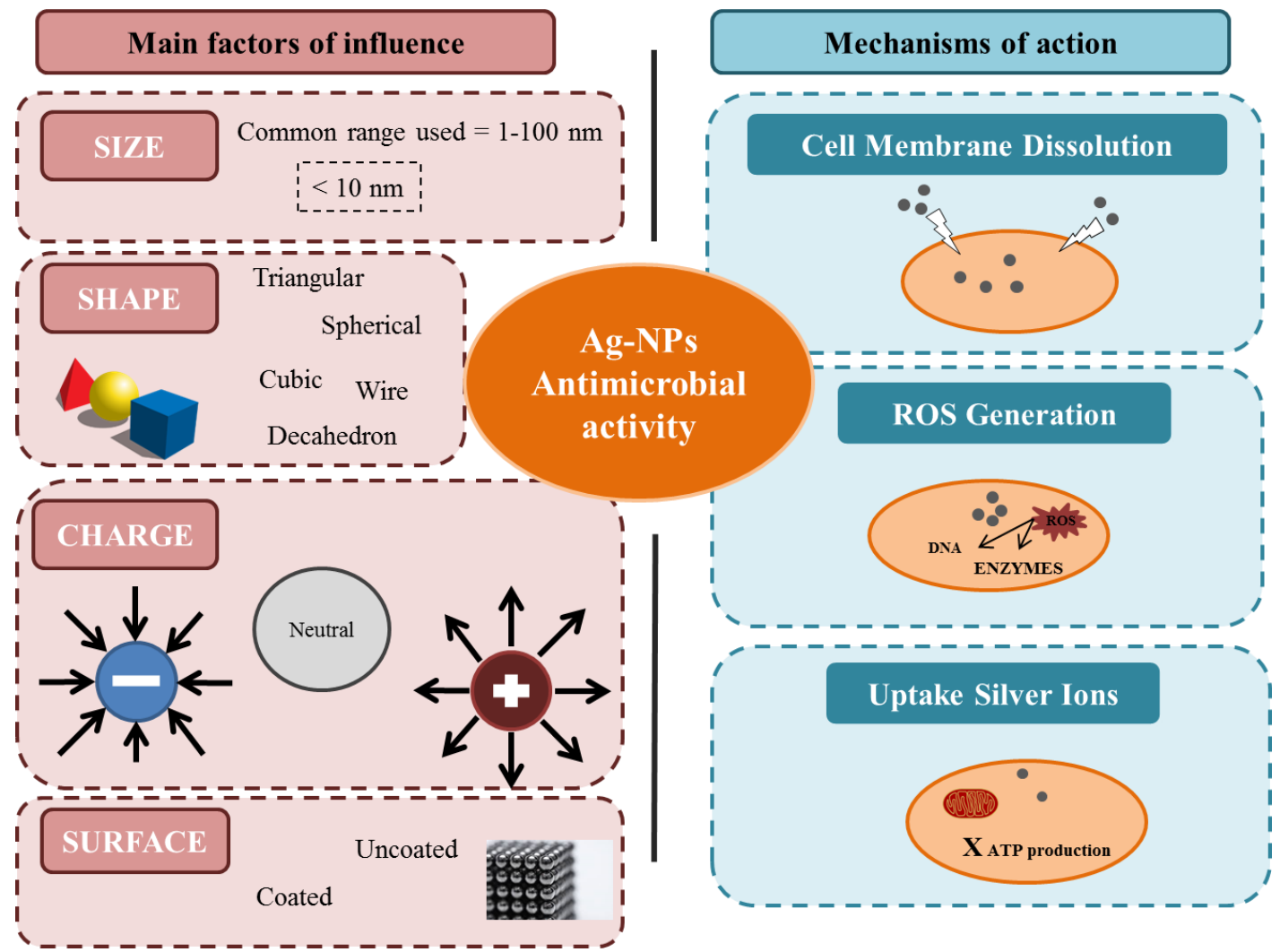

Figure 1. Main factors of influence and hypothetical mechanisms for the antimicrobial activity of silver nanoparticles.

On the other hand, the increased incorporation of silver nanoparticles into consumer products makes it essential to address their potential risk for human health. Nevertheless, there is still a lack of knowledge about their specific aspects of the intestinal uptake of silver nanoparticles [5]. The oral route of exposure has been poorly explored, despite the incorporation of such nanoparticles into packaging in contact with foods. After their ingestion, these nanoparticles pass through the digestive tract, where they may undergo physicochemical transformations, with consequences for the luminal environment, before crossing the epithelial barrier to reach the systemic compartment. Therefore, Ag-NPs toxicity and in particular, their effects at the gut level, are major concerns in the use and development of these nanomaterials.

This review presents a detailed description on the main applications of silver nanoparticles as antimicrobial agents for food control, as well as the current legislation concerning these materials. In addition, we summarize current knowledge about the impact of the dietary exposure to silver nanoparticles in human health with special emphasis in the gastrointestinal environment and microbiota, and highlight the areas where information is lacking. Finally, conclusions and future directions about both topics are summarized.

\section{Applications of Antimicrobial Silver Nanoparticles in the Food Industry}

Microbial food spoilage is a major global concern that can reduce the shelf life of food while increasing the risk of foodborne diseases. In this framework, the use of well-known potent antimicrobial agents such as silver nanoparticles constitutes an interesting approach. An overview of the effectiveness of silver nanoparticles to inhibit the growth of different microorganisms is shown in Table 1. 
Table 1. Recompilation of studies about the antimicrobial effects of Ag-NPs against foodborne pathogens.

\begin{tabular}{|c|c|c|c|c|c|c|}
\hline $\begin{array}{l}\text { Ag-NPs } \\
\text { Size }\end{array}$ & $\begin{array}{c}\mathrm{Ag}-\mathrm{NPs} \\
\text { Concentration }\end{array}$ & Gram (-) Pathogens & $\begin{array}{c}\text { Gram (+) } \\
\text { Pathogens }\end{array}$ & Yeast/Fungus & Main Results & Reference \\
\hline- & $\begin{array}{l}0.034 \mu \mathrm{g} \\
\mathrm{Ag} / \mathrm{mL}\end{array}$ & Escherichia coli $\mathrm{K} 12$ & - & - & $\begin{array}{l}2 \log \text { reduction of } E . \text { coli } \\
\text { after membrane filtration. }\end{array}$ & [29] \\
\hline $\begin{array}{l}\approx 7 \mathrm{~nm} \text { and } \\
27.5 \mathrm{~nm}\end{array}$ & $\begin{array}{c}0.26-26.5 \mathrm{mg} \\
\mathrm{Ag} / \text { dry g } \\
\text { paper }\end{array}$ & Escherichia coli & $\begin{array}{c}\text { Enterococcus } \\
\text { faecalis }\end{array}$ & - & $\begin{array}{l}\text { After filtration, the paper } \\
\text { with a higher content of } \\
\text { Ag-NPs almost } \\
\text { completely deactivated } \\
\text { bacterial growth. } \\
\text { Reductions of } 7 \text { and } 3 \mathrm{log} \\
\text { were produced for E. coli } \\
\text { and E. faecalis, } \\
\text { respectively. }\end{array}$ & [30] \\
\hline $\begin{array}{l}75 \mathrm{~nm} \\
\text { (spherical) } \\
\text { and 8-20 nm } \\
\text { (triangular) }\end{array}$ & - & $\begin{array}{l}\text { Escherichia coli, } \\
\text { Pseudomonas aeruginosa, } \\
\text { Salmonella typhi, } \\
\text { Acinetobacter baumannii, } \\
\text { Enterobacter cloacae, } \\
\text { Haemophilus influenzae, } \\
\text { Klebsiella pneumoniae, } \\
\text { Neisseria mucosa, Proteus } \\
\text { mirabilis, Serratia } \\
\text { odorifera, Vibrio } \\
\text { parahaemolyticus and } \\
\text { Paenibacillus koreensis }\end{array}$ & $\begin{array}{l}\text { Staphylococcus } \\
\text { aureus, } \\
\text { Bacillus } \\
\text { subtilis and } \\
\text { Paenibacillus } \\
\text { koreensis }\end{array}$ & - & $\begin{array}{l}\text { The highest antimicrobial } \\
\text { activity of the Ag-NPs } \\
\text { was against E. coli and } \\
\text { P. aeruginosa. For S. typhi } \\
\text { and B. subtilis this activity } \\
\text { was moderate and low for } \\
\text { S. aureus. }\end{array}$ & [26] \\
\hline $14.6 \mathrm{~nm}$ & $\begin{array}{c}0.2,0.5,1 \\
1.5,2 \mathrm{mg} / \mathrm{mL}\end{array}$ & $\begin{array}{l}\text { Escherichia coli, } \\
\text { Pseudomonas aeruginosa } \\
\text { and Klebsiella } \\
\text { pneumoniae }\end{array}$ & $\begin{array}{l}\text { Lactobacillus } \\
\text { rhamnosus } \\
\text { GG, Bacillus } \\
\text { cereus and } \\
\text { Listeria } \\
\text { monocytogenes }\end{array}$ & $\begin{array}{l}\text { Aspergillus } \\
\text { and } \\
\text { Penicillium }\end{array}$ & $\begin{array}{l}\text { Inhibition of bacterial } \\
\text { growth was dose } \\
\text { dependent. P. aeruginosa } \\
\text { was the bacteria most } \\
\text { sensitive to Ag-NPs, } \\
\text { followed by E. coli. On the } \\
\text { contrary L. monocytogenes } \\
\text { was the most resistant. }\end{array}$ & [31] \\
\hline $\begin{array}{l}10,20,40,60 \\
\text { and } 80 \mathrm{~nm}\end{array}$ & $\begin{array}{c}8 \mu \mathrm{g} \mathrm{Ag} / \mathrm{mL} \\
(10 \mathrm{~nm}), \\
11 \mu \mathrm{g} \mathrm{Ag} / \mathrm{mL} \\
(20 \mathrm{~nm}), 5 \mu \mathrm{g} \\
\mathrm{Ag} / \mathrm{mL}(40, \\
60 \text { and } \\
80 \mathrm{~nm})\end{array}$ & $\begin{array}{l}\text { Escherichia coli and } \\
\text { Pseudomonas fluorescens }\end{array}$ & - & $\begin{array}{l}\text { Saccharomyces } \\
\text { cerevisiae }\end{array}$ & $\begin{array}{l}\text { Nanoparticles of a size } \\
\text { equal to or less than } \\
10 \mathrm{~nm} \text { were more } \\
\text { bioavailable when } \\
\text { interacting with the cells. } \\
\text { It was also shown that the } \\
\text { toxicity of Ag-NPs } \\
\text { decreased with } \\
\text { increasing size. }\end{array}$ & [21] \\
\hline $\begin{array}{l}8 \mathrm{~nm}(59 \text { and } \\
83 \mathrm{~nm} \\
\text { hydrodynamic } \\
\text { size })\end{array}$ & $\begin{array}{c}0-400 \mu \mathrm{g} \\
\mathrm{Ag} / \mathrm{mL}\end{array}$ & $\begin{array}{l}\text { Proteus vulgaris and } \\
\text { Shigella sonnei }\end{array}$ & $\begin{array}{l}\text { Staphylococcus } \\
\text { aureus, } \\
\text { Bacillus } \\
\text { megaterium }\end{array}$ & - & $\begin{array}{l}\text { The smaller size of } \\
\text { Ag-NPs produced a } \\
\text { greater growth inhibition. } \\
\text { For both sizes the MIC } \\
\text { values for the bacteria } \\
\text { were between } \\
75-400 \mathrm{ug} / \mathrm{mL} \text {. }\end{array}$ & [20] \\
\hline- & $\begin{array}{l}4.5 \mu \mathrm{g} \mathrm{Ag} / \mathrm{g} \\
\text { film }\end{array}$ & $\begin{array}{l}\text { Pseudomonas and } \\
\text { Enterobacteriaceae }\end{array}$ & - & - & $\begin{array}{l}\text { No significant differences } \\
\text { were observed in the use } \\
\text { of the film with } \\
\text { nanoparticles compared } \\
\text { to the conventional film. }\end{array}$ & [32] \\
\hline $10-50 \mathrm{~nm}$ & $\begin{array}{l}197 \mu \mathrm{g} \\
\mathrm{Ag} / \mathrm{mL}\end{array}$ & $\begin{array}{l}\text { Campylobacter jejuni } \\
\text { (collection strain and } \\
\text { isolates of patients and } \\
\text { food chain) }\end{array}$ & - & - & $\begin{array}{l}\text { The concentrations } \\
\text { between } 9.85 \text { and } \\
39.4 \mu \mathrm{g} / \mathrm{mL} \text { were } \\
\text { bactericidal after } 24 \mathrm{~h} \text { of } \\
\text { incubation. In addition, } \\
\text { the lower concentrations } \\
(1.23 \text { and } 4.92 \mu \mathrm{g} / \mathrm{mL}) \\
\text { significantly inhibited the } \\
\text { growth of the collection } \\
\text { strain. }\end{array}$ & [33] \\
\hline
\end{tabular}


Table 1. Cont.

\begin{tabular}{|c|c|c|c|c|c|c|}
\hline $\begin{array}{l}\text { Ag-NPs } \\
\text { Size }\end{array}$ & $\begin{array}{c}\text { Ag-NPs } \\
\text { Concentration }\end{array}$ & Gram (-) Pathogens & $\begin{array}{c}\text { Gram (+) } \\
\text { Pathogens }\end{array}$ & Yeast/Fungus & Main Results & Reference \\
\hline- & - & Escherichia coli & $\begin{array}{l}\text { Staphylococcus } \\
\text { aureus }\end{array}$ & $\begin{array}{l}\text { Aspergillus } \\
\text { niger and } \\
\text { Penicillium } \\
\text { citrinum }\end{array}$ & $\begin{array}{l}\text { The antimicrobial activity } \\
\text { of the chitosan, laponite } \\
\text { and Ag-NPs hybrid film } \\
\text { turned out to be slightly } \\
\text { less than the chitosan film } \\
\text { because laponite } \\
\text { decreases the release of } \\
\text { silver. There was also a } \\
\text { greater inhibition of } \\
\text { gram-positive bacteria } \\
\text { compared to } \\
\text { gram-negative bacteria. }\end{array}$ & [34] \\
\hline $20-30 \mathrm{~nm}$ & $\begin{array}{c}2.37,4.75,9.5 \\
\text { and } 19 \mu \mathrm{g} \\
\mathrm{Ag} / \mathrm{mL}\end{array}$ & $\begin{array}{l}\text { Escherichia coli and } \\
\text { Salmonella typhimurium }\end{array}$ & - & - & $\begin{array}{l}\text { The concentration of } \\
4.75 \mu \mathrm{g} / \mathrm{mL} \text { Ag-NPs } \\
\text { completely inhibited the } \\
\text { growth of the two bacteria } \\
\text { and the concentration of } \\
9.5 \mu \mathrm{g} / \mathrm{mL} \text { was sufficient } \\
\text { to kill them. }\end{array}$ & [35] \\
\hline $47.3 \mathrm{~nm}$ & $\begin{array}{l}0-100 \mu \mathrm{g} \\
\mathrm{Ag} / \mathrm{mL}\end{array}$ & $\begin{array}{l}\text { Escherichia coli O157:H7, } \\
\text { Vibrio parahaemolyticu, } \\
\text { Pseudomonas aeruginosa } \\
\text { and Salmonella } \\
\text { typhimurium }\end{array}$ & $\begin{array}{l}\text { Listeria } \\
\text { monocytogenes } \\
\text { and } \\
\text { Staphylococcus } \\
\text { aureus }\end{array}$ & - & $\begin{array}{l}\text { Ag-NPs exerted a strong } \\
\text { antimicrobial activity } \\
\text { against all the pathogens } \\
\text { tested. MIC of } V \text {. } \\
\text { parahaemolyticus and } \\
\text { S. aureus were } 6.25 \mu \mathrm{g} / \mathrm{mL} \\
\text { and } 50 \mu \mathrm{g} / \mathrm{mL} \text {, } \\
\text { respectively, and MBCs of } \\
V \text {. parahaemolyticus and } S \text {. } \\
\text { aureus were } 12.5 \mu \mathrm{g} / \mathrm{mL} \\
\text { and } 100 \mu \mathrm{g} / \mathrm{mL} \text {, } \\
\text { respectively. }\end{array}$ & [36] \\
\hline $\begin{array}{l}\text { 6-25 nm } \\
\text { (chemical } \\
\text { synthesis) } \\
80-120 \mathrm{~nm} \\
\text { and } \\
40-100 \mathrm{~nm} \\
\text { (synthesized } \\
\text { with } \\
\text { Fusarium } \\
\text { nivale and } \\
\text { Penicillium } \\
\text { glabrum) }\end{array}$ & $\begin{array}{l}170 \mu \mathrm{g} \\
\mathrm{Ag} / \mathrm{mL}\end{array}$ & $\begin{array}{l}\text { Pseudomonas aeruginosa } \\
\text { PA01 4/4-15 }\end{array}$ & $\begin{array}{l}\text { Bacillus } \\
\text { cereus B 504T } \\
\text { UNIQEM, } \\
\text { Staphylococcus } \\
\text { aureus 209p }\end{array}$ & $\begin{array}{l}\text { Fusarium } \\
\text { oxysporum }\end{array}$ & $\begin{array}{l}\text { Chemically synthesized } \\
\text { AG-NPs inhibited } \\
\text { microbial growth at } 6 \mathrm{~h} \text { of } \\
\text { exposure, while with } \\
\text { microbiologically } \\
\text { synthesized nanoparticles } \\
\text { it occurred at } 24 \mathrm{~h} \text {. } \\
\text { S. aureus was the most } \\
\text { resistant microorganism } \\
\text { to both types of Ag-NPs. }\end{array}$ & [12] \\
\hline $5-15 \mathrm{~nm}$ & $\begin{array}{l}0.5,1.0,2.5 \\
5.0,7.5,10.0 \\
20.0 \text { and } \\
30.0 \mu \mathrm{g} \\
\mathrm{Ag} / \mathrm{mL}\end{array}$ & Escherichia coli & $\begin{array}{l}\text { Staphylococcus } \\
\text { aureus and } \\
\text { methicillin-resista } \\
\text { Staphylococcus } \\
\quad \text { aureus }\end{array}$ & ant - & $\begin{array}{l}\text { The nanoparticles } \\
\text { produced a total } \\
\text { inhibition of } E . \text { coli } \\
\text { growth at the } \\
\text { concentration of } \\
7.5 \mu \mathrm{g} / \mathrm{mL} \text {. On the } \\
\text { contrary, a concentration } \\
\text { of }>30 \mu \mathrm{g} / \mathrm{mL} \text { is required } \\
\text { for the complete } \\
\text { inhibition of } S \text {. aureus and } \\
\text { the resistant strain. }\end{array}$ & [15] \\
\hline $10-20 \mathrm{~nm}$ & $\begin{array}{l}8.34 \times 10^{-7} \\
3.61 \times 10^{-6} \\
5.79 \times 10^{-5} \\
\text { and } 4.63 \times \\
10^{-4} \mathrm{~mol} / \mathrm{L}\end{array}$ & Escherichia coli & $\begin{array}{l}\text { Staphylococcus } \\
\text { aureus }\end{array}$ & - & $\begin{array}{l}\text { Ag-NPs exerted a higher } \\
\text { antimicrobial activity } \\
\text { than the AgNO3 solution. } \\
\text { This activity was } \\
\text { concentration dependent } \\
\text { and greater than other } \\
\text { studies in which they use } \\
\text { green synthesis due to } \\
\text { their small size and } \\
\text { spherical shape. }\end{array}$ & [14] \\
\hline
\end{tabular}


Table 1. Cont.

\begin{tabular}{|c|c|c|c|c|c|c|}
\hline $\begin{array}{l}\text { Ag-NPs } \\
\text { Size }\end{array}$ & $\begin{array}{c}\text { Ag-NPs } \\
\text { Concentration }\end{array}$ & Gram (-) Pathogens & $\begin{array}{l}\text { Gram (+) } \\
\text { Pathogens }\end{array}$ & Yeast/Fungus & Main Results & Reference \\
\hline- & - & Salmonella typhimurium & $\begin{array}{c}\text { Staphylococcus } \\
\text { aureus }\end{array}$ & - & $\begin{array}{l}\text { The film that generated } \\
\text { Ag-NPs in situ exerted a } \\
\text { clear antimicrobial } \\
\text { activity against both } \\
\text { pathogens. A lower } \\
\text { microbial growth was } \\
\text { also observed when using } \\
\text { this material to store } \\
\text { chicken sausages for } \\
4 \text { days at } 4{ }^{\circ} \mathrm{C} \text { compared } \\
\text { to the traditional film. }\end{array}$ & [37] \\
\hline $8-15 \mathrm{~nm}$ & $\begin{array}{c}30,75,150, \\
\text { and } 300 \mu g \\
\mathrm{Ag} / \mathrm{mL}\end{array}$ & Escherichia coli O157:H7 & $\begin{array}{c}\text { Listeria } \\
\text { monocytogenes }\end{array}$ & - & $\begin{array}{l}\text { The material containing } \\
\text { Ag-NPs exerted a greater } \\
\text { antimicrobial activity } \\
\text { against } E \text {. coli than } \\
\text { against } L . \text { monocytogenes } \\
\text { due to the greater wall } \\
\text { thickness of the } \\
\text { gram-positive bacteria. }\end{array}$ & [38] \\
\hline
\end{tabular}

Among other relevant results, Silvan et al. [33] demonstrated the antibacterial effect of Ag-NPs against multi-drug resistant (MDR) Campylobacter strains isolated from the chicken food chain and clinical patients. In another study, nanoparticles synthesized through Forsythia suspensa fruit water extract showed antibacterial activities against the most common foodborne pathogens, including Listeria monocytogenes, Vibrio parahaemolyticus, Escherichia coli O157:H7 and Salmonella typhimurium [36]. Similarly, the Ag-NPs synthesized from jack fruit seeds showed an antibacterial effect against $E$. coli and S. typhimurium [35]. The toxic effect of Ag-NPs synthesized using a bacterial exopolysaccharide as a reducing and stabilizing agent against various food pathogens (L. monocytogenes, Aspergillus spp. and Penicillum spp.) was also demonstrated [31]. Based on these promising results and in order to improve the shelf life and safety of food, there are various food preservation and safety strategies in which Ag-NPs have been employed (or proposed to be employed) in the food industry (Figure 2). Specifically, in this section, we report on the last studies assessing the use of silver nanoparticles in food processing and food packaging, and also the current regulation about it.

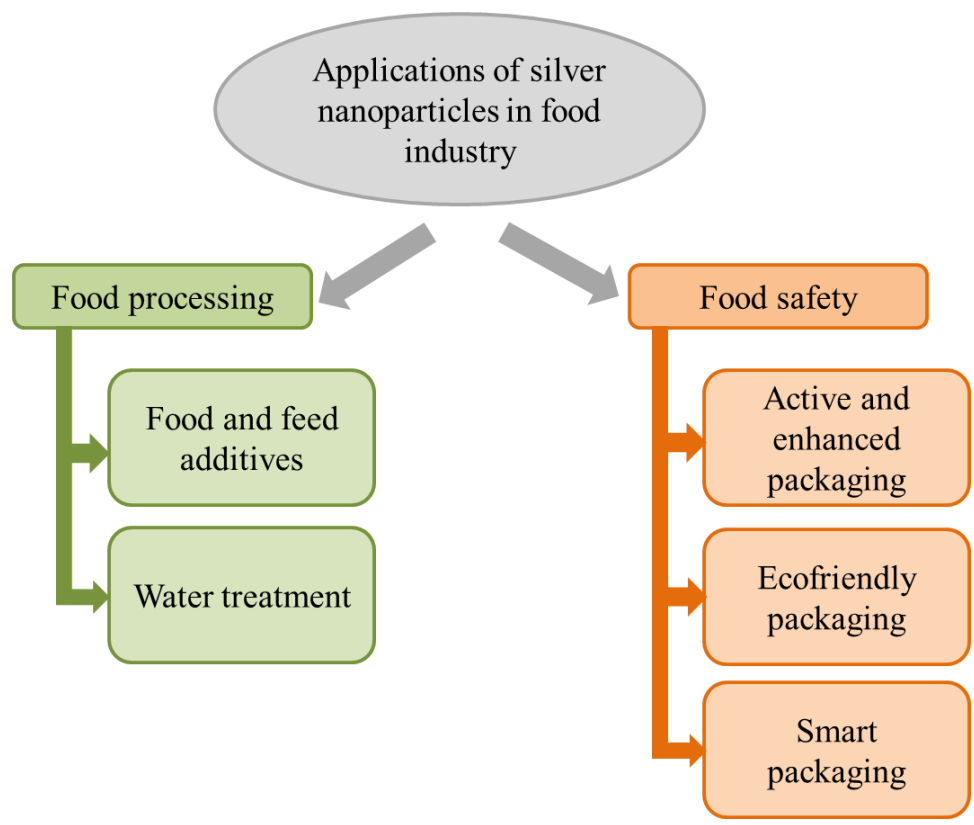

Figure 2. Classification of the use of Ag-NPs as antimicrobials in the food industry (adapted from Singh et al. [39]). 


\subsection{Food Processing (Preservation)}

As feed additives, Ag-NPs has shown to be effective in the reduction of potentially pathogenic organisms such as E. coli and Clostridium perfringens [40-43], which could reduce the use of antibiotics in livestock [43]. Additionally, some Ag-NPs have also showed effective antiparasitic activity [44-46].

Ag-NPs have also been successfully applied in water treatment by incorporating them to filters with foam or by impregnating ultrafiltration membranes [29,30]. Although the investigation of Ag-NPs as a food additive is not very widespread, attractive attempts have been made to replace the use of sulfur dioxide by the use of antimicrobial nanoparticles. This is the case in the wine industry. For example, the effectiveness of a colloidal silver complex of a size $<1 \mathrm{~nm}$ was studied, managing to control the growth of lactic acid bacteria [47,48]. Another study confirmed the antimicrobial activity of two coated Ag-NPs against lactic acid bacteria and other microorganisms such as S. aureus and E. coli, with potential application in winemaking [49].

\subsection{Food Packaging (Safety)}

Food packaging is one of the areas where nanoparticles research and use is most relevant. The need of protection against foodborne diseases and the requirement of consumers to extend the useful life of the products urged the development of antimicrobial food packaging, special packaging that releases active biocide substances in order to improve the quality of the food [50]. The use of natural substances, such as green tea and chilto extracts and essential oils in packaging materials has already been investigated [51-53] but the use of Ag-NPs would be a more effective alternative because their antimicrobial activity is greater than phytochemicals. Nanotechnology in food packaging can be divided into three categories: (i) active packaging, (ii) ecofriendly packaging, and (iii) smart packaging, although packaging combinations are also possible (i.e., active and ecofriendly packing). In active packaging, the silver nanoparticles interact directly with the food or the environment polymer matrix which can be a non-degradable polymeric film such as polyethylene (PE), polyvinyl chloride (PVC) and ethylene vinyl alcohol $(\mathrm{EVOH})$ or a biodegradable edible coating film made by a polymer or a stabilizing agent (ecofriendly packaging). In addition, Ag-NPs offer a good stability and slow release rates of silver ions in stored foods which makes them suitable candidates to be used in food packaging [54]. In line with this, Yu et al. [38] demonstrated the antibacterial effect of a material composed of Ag-NPs and cellulose nanofibrils against E. coli and L. monocytogenes. Similarly, silver nanoparticles immobilized with laponite showed a good growth inhibitory activity against $E$. coli, S. aureus, A. niger and P. citrinum [34]. Similar effects of silver nanoparticles against chicken meat (breasts and sausages) were found. The bacterial growth of $S$. aureus, S. typhimurium decreased, although there were also increases in cadaverine and thiamine [32,37]. On the other hand, the protective effect of silver nanoparticles in long-term packaging of nuts has also been demonstrated. The 3\% silver package achieved a significant reduction in the presence of mold and coliforms and also achieved an antioxidant effect. Finally, the silver nanoparticles had a significant effect on increasing the shelf life of nuts [55].

At the framework of food safety, smart packaging, that is, packing with biosensors for the detection of pathogens represents a novel approach for food preservation, although still under development. The operation mode is based on the union or reaction of biological components with target species (microorganisms, toxins, etc.) and the transformation into detectable signals, which leads to the rapid detection of food contaminants [56]. Examples can be found in studies such as Abbaspour et al. [57] which described a selective sandwich biosensor for the detection of $S$. aureus. Combination of fluorescent carbon points (CDF) with silver nanoparticles has been reported for the detection and elimination of bacteria such as E. coli and S. aureus at low concentrations [58]. In the same way, the conjugated polyelectrolytes (CPs)-silver nanostructure pair has showed a high detection power against E. coli [59]. 


\subsection{Regulation about Silver Nanoparticles Use in Foods and Food Industry Packaging (Safety)}

The panel of the European Food Safety Agency (EFSA) on food additives and sources of nutrients added to food determined that there is insufficient information on Ag to assess its risk and, therefore, in the European Union (EU), Ag-NPs are not allowed in food supplements or food packaging unless authorized. EFSA has also provided Ag migration limits from the packaging $(<0.05 \mathrm{mg} / \mathrm{L}$ in water and $<0.05 \mathrm{mg} / \mathrm{kg}$ in food [60,61]. Therefore, manufacturers must carry out migration evaluations as well as genotoxicity, absorption, distribution, metabolism and in vitro excretion tests [60,61]. With all this information, EFSA will carry out a risk assessment of the specific case to determine if that package can be marketed or not. To date there are no known products that have been approved. On the other hand, in November 2015, Regulation (EU) 2015/2283 of the European Parliament and the European Council on new foods was approved. In this regulation, it appears the definition of "artificial nanomaterial" to include, within this new category ("novel foods"), all the foods that consist or contain artificial nanomaterials [62]. In spite of this, Ag-NPs still do not appear in the legislation of allowed food additives or in the materials in contact with food. Otherwise, in the United States, these regulations are influenced by the existing regulatory restrictions on the release of silver to the environment and are the responsibility of three agencies: the Environmental Protection Agency (EPA), the Food and Drug Administration (FDA) and the agency of the Institute National Occupational Safety and Health (NIOSH). The FDA published a guide for the use of nanotechnology in food or materials in contact with them and recommended that manufacturers study and prepare a toxicological profile for each container with nanomaterials $[63,64]$.

As mentioned above, one of the problems of using these nanoparticles in food packaging is silver migration. Echegoyén and Nerín [65] conducted an analysis of the form of silver migration, whether ions or particles, into food simulants. They demonstrated that silver migrated to food and was dependent on food and warming, with acidic foods and oven heating presenting a higher migration. However, in their study, they found that Ag migration is well below the maximum migration limits established by European Union legislation. However, other studies did not observe any temperature or time-dependent increase in the migration of Ag packaged foods [66]. Gallocchio et al. [67] tested a container with Ag-NPs to store chicken breasts and did not observe that the silver content of the breasts was higher than that allowed by the EU.

\section{Impact of Dietary Exposure to Silver Nanoparticles in Health: Gut Nanotoxicology Effects}

As the investigation into the application of nanotechnology in the food sector increases, the potential of nanotechnology in food science/industry also expands and consequently, so does the human exposure to these substances. In the case of antimicrobial silver nanoparticles with application in food industry, the subject of this review, the main human exposure source is through the oral-gastrointestinal tract [68]. The mean dietary exposure level of Ag-NPs is estimated at 70-90 $\mu \mathrm{g} / \mathrm{day}$ [69]. After ingestion, the Ag-NPs come in contact with lumen of the oral cavity and esophagus. There is little published information on the absorption rate of particulates through the epithelium of these two compartments, probably due to both a low surface area and a short residence time for most food matrices [68]. After that, during the gastrointestinal digestion process in the stomach and small intestine, the interaction of Ag-NPs with biological fluids can lead to its agglomeration, aggregation, and dissolution [69-73]. In addition, silver nanoparticle absorption (transcellular and paracellular transport and vesicular phagocytosis) through the gastrointestinal tract epithelium could take place. Finally, the nanoparticles that escape the absorption process reach the colon where they could modulate the composition and/or activity of gut microbiota, affecting the production and toxicity of bacterial metabolites [69]. Part of the initial intake of nanoparticles could be extracted in feces. According to the anatomy of the gastrointestinal tract, several environments characterizdc by specific microbiota composition are found. Gut microbiota harbors more than 100,000 billion microorganisms, including bacteria, fungi, viruses, protozoa and archaea, with bacteria representing a majority. The dominant gut bacterial phyla are the Firmicutes (including Clostridium, Enterococcus, Lactobacillus, and Ruminococcus genera) and 
Bacteroidetes (including Bacteroides and Prevotella genera). These bacteria play an important role in the development and conservation of host health. Gut microbes play a role in human physiology through several mechanisms, including their contribution to nutrient and xenobiotic metabolism (e.g., synthesis of vitamins, digestion of oligo, and polysaccharides, drugs, etc.) and to the regulation of immune and neurodendocrine functions. Some of these effects are mediated by products of bacterial metabolism, such as short-chain fatty acids (SCFA), including propionate, butyrate or acetate, which influence the gut barrier, the inflammatory tone and the metabolic homeostatic control in different tissues [74]. To date, little is known about the effect of nanoparticles on the intestinal microbiota, but what is known is that there are numerous factors that can produce an imbalance in the intestinal bacterial populations, like food, triggering certain diseases. That is why the investigation of the NPs-gut microbiota relationship is so important and should continue $[68,69]$.

The physical and chemical transformations of Ag-NPs during the gastrointestinal digestion could involve modifications in their toxic effect. Despite the specific features of these particles and the differences among them, they all display a close relationship between physicochemical reactivity and bioavailability/biopersistence in the gastrointestinal tract. Recently, Mercier-Bonin et al. [68] and Bouwmeester et al. [72] discussed the potential impact of the luminal and gastrointestinal environment on nanomaterial properties and toxicity studies. In this section, with a specific focus on silver nanoparticles, we report in vitro and in vivo studies considering both local and systemic levels effects, with a particular emphasis on their impact on gut microbiota.

\subsection{In Vitro Studies: Static and Dynamic Gut Simulators and Epithelium Cell Models}

Today, several in vitro models, from cell models to static and dynamic gastrointestinal models can be used alone or in combination for the study of Ag-NPs toxicity. As mentioned above, concentration/dose is a very important factor for the use of nanoparticles as an antimicrobial agent in the food field. In general, cytotoxicity of Ag-NPs is concentration-dependent. Moreover, depending on the cell type, silver nanoparticles cytotoxicity varies notably, and this should be taken into consideration for their application in consumer products [75]. As said above in relation to their antimicrobial activity, size, shape, charge and surface are also factors that affect the cytotoxicity of these nanoparticles. Ag-NPs' security depends on their state as they can form aggregates during their synthesis and use due to surface charge or they are covered by a high viscosity substance or suspended in a high viscosity environment. It has been shown that coated silver nanoparticles have lower cytotoxic due to the stabilization effect of the coating, which in turn, depends on the coating material and the thickness of the layer [76,77].

Different studies have evaluated the cytotoxic effect of silver nanoparticles in various human cell lines trying to understand the possible risks after exposure or ingestion (Table 2). However, today there are not many studies that evaluated the effect of silver nanoparticles in the oral cavity and the evaluation of the effect of these nanoparticles on oral microbiota is even more limited [68]. In one of these studies, it was found that Ag-NPs increased oxidative stress, inflammation and apoptosis in the human gingival fibroblast cell line (CRL-2014) [78]. Likewise, Niska et al. [79] observed that Ag-NP induced cell death in a concentration-dependent manner, not being toxic until concentrations greater than $40 \mu \mathrm{g} / \mathrm{mL}$ on human gingival fibroblasts (HGF-1). On the other hand, Hernández-Sierra et al. [80] studied the effect of Ag-NPs of different sizes of periodontal fibroblasts extracted from volunteers. They concluded that only nanoparticles with a size smaller than $20 \mathrm{~nm}$ increased the cytotoxicity of fibroblasts. Another study with human periodontal fibroblasts, specifically with the cell line HPLF, found that nanoparticles at low concentrations $(\leq 16 \mu \mathrm{g} / \mathrm{mL})$ had little influence on proliferation and cell cycle, while at high concentrations ( 32 and $64 \mu \mathrm{g} / \mathrm{mL}$ ), they inhibited cell proliferation and significantly changed morphology [81]. The effect of Ag-NPs on oral bacteria has also been evaluated, with bacteria of the genus Streptococcus being more sensitive to them [82]. In another work, it was observed how the MIC and MBC of the silver nanoparticles was between 100 and $250 \mu \mathrm{g} / \mathrm{mL}$ for peri-implantitis pathogens [83]. On the other hand, Lu et al. [19] reported a MIC range between 25 and $50 \mu \mathrm{g} / \mathrm{mL}$ and this could be due to the smaller size of the nanoparticles used. 
Table 2. Studies regarding silver nanoparticles cytotoxicity effects in several cell lines.

\begin{tabular}{|c|c|c|c|}
\hline Cell Line & Ag-NPs Size & Main Results & Reference \\
\hline $\begin{array}{l}\text { Periodontal fibroblasts } \\
\text { extracted from } \\
\text { volunteers }\end{array}$ & $\begin{array}{l}<10 \mathrm{~nm}, 15-20 \mathrm{~nm}, \\
\text { and } 80-100 \mathrm{~nm}\end{array}$ & $\begin{array}{l}\text { Small-sized Ag-NPs }(<20 \mathrm{~nm}) \\
\text { increased cytotoxicity in cells in a } \\
\text { dose and time dependent manner. }\end{array}$ & [80] \\
\hline $\begin{array}{l}\text { Human gingival } \\
\text { fibroblast (CRL-2014) }\end{array}$ & $2 \mathrm{~nm}$ & $\begin{array}{l}\text { Ag-NPs increased oxidative stress, } \\
\text { inflammation and cell apoptosis. }\end{array}$ & [78] \\
\hline $\begin{array}{l}\text { Human gingival } \\
\text { fibroblasts (HGF-1) }\end{array}$ & $10 \mathrm{~nm}$ & $\begin{array}{l}\text { All the nanoparticles tested were less } \\
\text { toxic and exerted a greater } \\
\text { antimicrobial action than the silver } \\
\text { nitrate solution. }\end{array}$ & [79] \\
\hline $\begin{array}{l}\text { Human periodontal } \\
\text { fibroblasts (HPLF) }\end{array}$ & - & $\begin{array}{l}\text { Ag-NPs at low concentration did not } \\
\text { alter morphology or cell proliferation, } \\
\text { while at high concentration they } \\
\text { significantly altered morphology, } \\
\text { inhibited proliferation, and stopped } \\
\text { cell cycle. }\end{array}$ & [81] \\
\hline $\begin{array}{l}\text { Human colon epithelial } \\
\text { cells (Caco-2) }\end{array}$ & - & $\begin{array}{l}\text { There were no significant differences } \\
\text { in cell viability between digested and } \\
\text { undigested nanoparticles up to a } \\
\text { concentration of } 40 \mu \mathrm{g} / \mathrm{mL} \text {. There was } \\
\text { a viability reduction }(65 \%) \text { when } \\
\text { adding a food matrix. }\end{array}$ & [84] \\
\hline $\begin{array}{l}\text { EpiIntestinal, EpiOral } \\
\text { and EpiGinvival tissues }\end{array}$ & $\begin{array}{l}16 \mathrm{~nm} \text { in average } \\
\text { with sporadic } \\
\text { occurrence of } \\
\text { particles with a size } \\
\text { of around } 80 \mathrm{~nm}\end{array}$ & $\begin{array}{l}\text { Ag-NPs did not affect the viability of } \\
\text { EpiOral and EpiGingival tissues. In } \\
\text { addition, the release of IL-1 decreased } \\
\text { significantly in EpiOral tissue. On the } \\
\text { other hand, exposure of the } \\
\text { EpiIntestinal tissue to gastric fluids } \\
\text { with or without AG-NPs produced a } \\
\text { slight decrease in viability. }\end{array}$ & [85] \\
\hline $\begin{array}{l}\text { Human colon epithelial } \\
\text { cells (HT-28 and } \\
\text { HCT-116) }\end{array}$ & $6 \mathrm{~nm}$ & $\begin{array}{l}\text { After } 24 \mathrm{~h} \text { of exposure with Ag-NPS, a } \\
\text { decrease in dose-dependent cell } \\
\text { viability was observed }(2-10 \mu \mathrm{g} / \mathrm{mL}) \text {. } \\
\text { A cytotoxicity of approximately } 50 \% \\
\text { was reached at a concentration of } \\
4 \mu \mathrm{g} / \mathrm{mL} \text {. }\end{array}$ & [86] \\
\hline $\begin{array}{l}\text { Human colon epithelial } \\
\text { cells (HT-29 and Caco-2) } \\
\text { and colon regular cells } \\
\text { (CCD-18) }\end{array}$ & $10-50 \mathrm{~nm}$ & $\begin{array}{l}\text { Cytotoxicity occurred in the cells at a } \\
\text { concentration of Ag-NPs between } 9.85 \\
\text { and } 39.4 \mu \mathrm{g} / \mathrm{mL} \text {. }\end{array}$ & [33] \\
\hline $\begin{array}{l}\text { Human colon epithelial } \\
\text { cells (Caco-2) }\end{array}$ & $\approx 7.74 \mathrm{~nm}$ & $\begin{array}{l}\text { In this work, there was no significant } \\
\text { decrease in cell viability after } 24 \mathrm{~h} \text { at a } \\
\text { concentration of } 100 \mu \mathrm{g} / \mathrm{mL} \text {. }\end{array}$ & [87] \\
\hline $\begin{array}{c}\text { Human colon } \\
\text { epithelial cells } \\
\text { (Caco-2/HT-29-MTX) }\end{array}$ & $51-52 \mathrm{~nm}$ & $\begin{array}{l}\text { Cellular uptake decreased when using } \\
\text { digested versus undigested Ag-NPs } \\
\text { and the nanoparticles coated with } \\
\text { lipolic acid dissolved to a greater } \\
\text { extent than those coated with citrate. }\end{array}$ & [88] \\
\hline $\begin{array}{l}\text { Human colon epithelial } \\
\text { cells (Caco-2) }\end{array}$ & $\begin{array}{c}\text { 5-25 nm for } \\
\text { PEG-AgNPs 20; } \\
4-6 \mathrm{~nm} \text { and } 10-50 \mathrm{~nm} \\
\text { for GSH-AgNPs }\end{array}$ & $\begin{array}{l}\text { A significant decrease in cell viability } \\
\text { was observed by exposing cells to } \\
\text { digested nanoparticles (both coatings), } \\
\text { but not to undigested nanoparticles. }\end{array}$ & [74] \\
\hline
\end{tabular}


Table 2. Cont.

\begin{tabular}{|c|c|c|c|}
\hline Cell Line & Ag-NPs Size & Main Results & Reference \\
\hline $\begin{array}{l}\text { Rat brain microvessel } \\
\text { endothelial cells } \\
\text { (rBMEC) }\end{array}$ & 25,50 and $80 \mathrm{~nm}$ & $\begin{array}{l}\text { Ag-NPs were more cytotoxic at lower } \\
\text { concentrations for a size of } 25 \text { and } \\
40 \mathrm{~nm} \text {. On the contrary, for a size of } \\
80 \mathrm{~nm} \text { greater concentrations } \\
\text { were needed. }\end{array}$ & [89] \\
\hline $\begin{array}{l}\text { Human breast epithelial } \\
\text { cells (MCF-7) }\end{array}$ & $20-80 \mathrm{~nm}$ & $\begin{array}{l}\text { Ag-NPs caused apoptosis and } \\
\text { necrosis in a dose-dependent manner } \\
\text { to a concentration of } 80 \mu \mathrm{g} / \mathrm{mL} \text {. At } \\
\text { higher concentrations, the apoptotic } \\
\text { effect decreased while the necrotic } \\
\text { effect became prominent. }\end{array}$ & [90] \\
\hline $\begin{array}{l}\text { Human liver epithelial } \\
\text { cells (HepG2) }\end{array}$ & 10 and $100 \mathrm{~nm}$ & $\begin{array}{l}\text { Ag-NPs at low doses increased } \\
\text { cell proliferation. }\end{array}$ & [91] \\
\hline $\begin{array}{l}\text { Human breast epithelial } \\
\text { cells (MCF-7) }\end{array}$ & $31.4 \mathrm{~nm}$ & $\begin{array}{l}\text { Ag-NPs at a concentration of } \\
60 \mu \mathrm{g} / \mathrm{mL} \text { exhibited a cytotoxicity of } \\
70 \% \text { against the cell line. It was also } \\
\text { observed that AgNP were much less } \\
\text { cytotoxic when tested against a } \\
\text { non-cancerous cell line. }\end{array}$ & [92] \\
\hline $\begin{array}{l}\text { Human dermal fibroblast } \\
\text { (NHDF) }\end{array}$ & $20-45 \mathrm{~nm}$ & $\begin{array}{l}\text { Except for the sodium oleate and } \\
\text { sodium dodecyl sulfate solutions, the } \\
\text { rest prevented the aggregation of the } \\
\text { nanoparticles, stabilized them and did } \\
\text { not produce a significant cytotoxic } \\
\text { effect on the cells. }\end{array}$ & [76] \\
\hline
\end{tabular}

Unlike what happens with the oral cavity, there are numerous in vitro investigations on the effect of silver nanoparticles in the intestine (Table 2). It was observed that the intake of Ag-NPs within a food matrix increased its absorption by colon epithelial cells, the opposite being the case when ingested without food. This shows us the ease with which nanoparticles can reach our intestines due to their consumption along with food [84]. The toxicity difference between digested and undigested silver nanoparticles was also studied. It was possible to verify how the undigested ones were mostly captured by the cellular model Caco-2/HT29-MTX [88]. In the study of Silvan et al. [33], exposure of GSH-Ag NPs to epithelial cells (HT-29, Caco-2 and CCD-18) showed a dose-dependent cytotoxic effect and no significant cytotoxicity occurred until concentrations of $4.93 \mu \mathrm{g} / \mathrm{mL}$. This is supported by other works in which the toxicity of silver nanoparticles is usually in the range of 10 to $100 \mu \mathrm{g}$ [93]. It was observed in the work of Vila et al. [87] that the exposure of small-sized Ag-NPs $(\approx 8 \mathrm{~nm})$ at a concentration of $100 \mu \mathrm{g} / \mathrm{mL}$ only reached $20 \%$ cytotoxicity in Caco- 2 cells. It was also shown that cell integrity was not altered using concentrations below $50 \mu \mathrm{g} / \mathrm{mL}$.

The toxicity of these nanoparticles has not only been studied on oral and intestinal cell lines. There is a study in which non-cytotoxic doses of Ag-NPs were used against the HepG2 cell line. Moreover, at low doses ( 2 and $4 \mathrm{mg} / \mathrm{L}$ ), Ag-NPs presented "hormesis" effects by accelerating cell proliferation and an activation of mitogen-activated protein kinase (MAPK) [91]. On the other hand, Khorrami et al. [92] described a cytotoxicity level of $70 \%$, at concentrations between 10 and $60 \mu \mathrm{g} / \mathrm{mL}$, on the MCF-7 breast cancer cell line, while for the L-929 cell line (non-carcinogenic), it was only $15 \%$. In another study, the toxic effect of Ag-NPs on the MCF-7 cell line was also evaluated. Cellular cytotoxicity was observed from a nanoparticle concentration of $10 \mu \mathrm{g} / \mathrm{mL}$ [90]. This is opening the door to the use of this nanomaterial against cancer cells and therefore, to be a possible cancer therapy, alone or in combination with other existing methods $[86,94]$. Other studies reported that Ag-NPs may interact with the cerebral microvasculature producing a proinflammatory cascade in rat brain microvessel 
endothelial cells, as well as that larger NPs were less toxic, and blood-brain barrier (BBB) dysfunction and astrocyte swelling causing neuronal degeneration [89,95].

In reference to static models of gastrointestinal digestion (Table 3), there is one study that showed that Ag-NPs with a size of $60 \mathrm{~nm}$ and a concentration of $10 \mathrm{mg} / \mathrm{mL}$ (1661 particles/mL) in the presence of proteins survived the extreme conditions of the digestion and reached the intestine [71]. This probably means that epithelial cells of the intestine would be exposed to these nanoparticles, causing cellular damage. On the contrary, in the absence of proteins, the fraction of NPs that reached the intestine was smaller [71]. In other works they also studied the effect of nanoparticles during the passage through the gastrointestinal tract. It was found that by contacting them with synthetic human stomach fluid, the Ag-NPs aggregated significantly and also released ionic silver that was physically associated with the aggregates of particles such as silver chloride. In addition, it was seen that NPs smaller than $10 \mathrm{~nm}$ were added to a greater extent than larger one [96]. It was also demonstrated that depending on the composition and $\mathrm{pH}$, the morphology and the size of the Ag-NPs changed when passing through the different fluids (simulated saliva and gastric and intestinal fluids); in addition, there was only a low toxicity in a pilot study of reconstituted human tissues model [85]. When Ag-NPs interact with proteins, a corona is always formed and it decreases the entry of nanoparticles into cells and therefore, cellular toxicity decreases [97]. Gil-Sánchez et al. [74] evaluated the effect of static in vitro digestion on silver nanoparticles with two types of coating. It was observed that the glutathione-coated nanoparticles agglomerated less than those that had the polyethylene glycol coating and were less toxic to colon cells. Studying the changes of NPs in dynamic models is more limited. In the work of Cueva et al. [98], the dynamic gastrointestinal simulator simgi ${ }^{\circledR}$ was used to digest Ag-NPs and study their effect on the colonic microbiota (Table 3). They did not observe changes in the bacterial composition or in the production of ammonium ions during the simulations, so it was concluded that Ag-NPs did not alter the composition and metabolic activity of the human intestinal microbiota. Another dynamic study showed that $90 \%$ of Ag-NPs were already dissolved by passing through the stomach and that many of the released ions bind to the food matrix. This results in less bioavailable ions and therefore, less toxicity (Table 3) [73].

Table 3. Studies in in vitro static and gastrointestinal simulation models regarding silver nanoparticles effects at gut level and microbiota.

\begin{tabular}{|c|c|c|c|}
\hline Static/Dynamic & Particle Size & Main Results & Reference \\
\hline Static & Ag-NPs $10-50 \mathrm{~nm}$ & $\begin{array}{l}\text { The range of MIC and MBC for oral } \\
\text { bacteria was between } 100 \text { and } \\
250 \mu \mathrm{g} / \mathrm{mL} \text {. Of the four oral bacteria } \\
\text { tested, the most sensitive to silver } \\
\text { nanoparticles were Porphyromonas } \\
\text { gingivalis and Fusobacterium nucleatum. }\end{array}$ & [83] \\
\hline Static & Ag-NPs 5, 15 and $55 \mathrm{~nm}$ & $\begin{array}{l}\text { In this work it was observed that for the } \\
\text { smaller nanoparticles the MIC was } \\
\text { between } 25 \text { and } 50 \mu \mathrm{g} / \mathrm{mL} \text {. Oral aerobic } \\
\text { bacteria were more susceptible than } \\
\text { anaerobic bacteria. }\end{array}$ & [19] \\
\hline Static & Ag-NPs 30-50 nm & $\begin{array}{l}\text { A MIC between } 15 \text { and } 90 \mu \mathrm{g} / \mathrm{mL} \text { was } \\
\text { reported for the exposure of Ag-NPs } \\
\text { against } 5 \text { oral pathogens, much lower } \\
\text { than for chlorhexidine. }\end{array}$ & [82] \\
\hline Static & Ag-NPs $60 \mathrm{~nm}$ & $\begin{array}{l}\text { AG-NPs of a size of } 60 \mathrm{~nm} \text { digested } \\
\text { under physiological conditions can } \\
\text { reach the wall of the intestine. It was } \\
\text { also observed that after ingestion of } \mathrm{Ag} \\
+ \text { ions nanoparticles ended up forming. }\end{array}$ & [71] \\
\hline
\end{tabular}


Table 3. Cont.

\begin{tabular}{|c|c|c|c|}
\hline Static/Dynamic & Particle Size & Main Results & Reference \\
\hline Static & Ag-NPs 10 and $75 \mathrm{~nm}$ & $\begin{array}{l}\text { After the intake of Ag-NPs, these } \\
\text { nanoparticles can be aggregated and } \\
\text { chemically modified in the stomach } \\
\text { depending on the size and surface } \\
\text { chemistries. }\end{array}$ & [96] \\
\hline Static & Ag-NPs $10 \mathrm{~nm}$ & $\begin{array}{l}\text { There was a reduction in the production } \\
\text { of capric and stearic fatty acids after } \\
\text { exposure of the human feces sample to } \\
\text { Ag-NPs, while palmitic acid increased. } \\
\text { The presence of Bacteroidetes was also } \\
\text { drastically reduced. }\end{array}$ & [99] \\
\hline Static & $\begin{array}{l}16 \mathrm{~nm} \text { in average with } \\
\text { sporadic occurrence of } \\
\text { particles with a size of } \\
\text { around } 80 \mathrm{~nm}\end{array}$ & $\begin{array}{l}\text { The size and morphology of the Ag-NPs } \\
\text { changed due to the action of different } \\
\text { gastric fluids and digestive enzymes. } \\
\text { The study showed that nanoparticles } \\
\text { agglomerate and partially react to form } \\
\text { AgCl during exposure to fluids. }\end{array}$ & [85] \\
\hline Static & Ag-NPs $14 \mathrm{~nm}$ & $\begin{array}{l}\text { A decrease in Bacteroidetes and an } \\
\text { increase in Firmicutes was observed, } \\
\text { resulting in an alteration of the } \\
\text { Firmicutes/Bacteroidetes ratio. Exposure } \\
\text { with Ag-NPs for } 24 \text { h also altered the } \\
\text { Faecalibacterium prausnitzii and } \\
\text { Clostridium coccoides/ } \\
\text { Eubacterium rectal taxa. }\end{array}$ & [100] \\
\hline Static & $\begin{array}{c}\text { 5-25 } \mathrm{nm} \text { for PEG-AgNPs } \\
20 ; 4-6 \mathrm{~nm} \text { and } 10-50 \mathrm{~nm} \\
\text { for GSH-AgNPs }\end{array}$ & $\begin{array}{l}\text { AgNPs agglomerated less and were less } \\
\text { toxic in colon cells than PEG-AgNPs } 20 .\end{array}$ & [74] \\
\hline Dynamic & Ag-NPs 15 and $40 \mathrm{~nm}$ & $\begin{array}{l}\text { It was observed that } 90 \% \text { of the silver } \\
\text { nanoparticles had dissolved as they } \\
\text { passed through the stomach and the } \\
\text { resulting ions joined the digestive } \\
\text { matrices. }\end{array}$ & [73] \\
\hline $\begin{array}{l}\text { Dynamic } \\
\text { SIMulator of the } \\
\text { GastroIntestinal } \\
\text { tract (simgi }{ }^{\circledR} \text { ) }\end{array}$ & $\begin{array}{c}3-5 \mathrm{~nm} \text { and } 10-25 \mathrm{~nm} \text { for } \\
\text { PEG-AgNPs 20; } 4-6 \mathrm{~nm} \\
\text { and 10-50 nm for } \\
\text { GSH-AgNPs }\end{array}$ & $\begin{array}{l}\text { Ingestion of Ag-NPs did not alter the } \\
\text { microbial composition of the intestine } \\
\text { or the metabolic activity of the bacteria. } \\
\text { It was also observed how during the } \\
\text { digestion the nanoparticle size was } \\
\text { predominantly } 3-5 \mathrm{~nm} \text {, although small } \\
\text { populations of agglomerates of these } \\
\text { small nanoparticles were found. }\end{array}$ & [98] \\
\hline
\end{tabular}

A limited number of studies on the interaction of nanomaterials with the microbiome are available, most of them in rodents. In one in vitro study, it was observed that the Ag-NPs modified the Firmicutes/Bacteroidetes phylum ratio, increasing Firmicutes and decreasing Bacteroidetes. It was seen that the nanoparticles altered the intestinal microbiota as would a metabolic and inflammatory disease [100]. On the other hand, after exposure of silver nanoparticles $(10 \mathrm{~nm})$ to a concentration range of $0-100 \mu \mathrm{g} / \mathrm{mL}$, a marked decrease in saturated fatty acids was observed, except in palmitic acid, which increased by 26-32\%. The observation of these variations led to the sequencing of bacterial DNA. According to the results of Das et al. [99], Ag-NP ingestion, either deliberate or inadvertent, could have negative consequences on our intestinal microbiota, as evidenced by a significant decreasing of Bacteroidetes due to both ionic silver (AgCl; 25-200 mg/L) and nanosilver-mediated changes. 


\subsection{In Vivo Studies: Animal and Human Trials}

When conducting studies in vivo, five main types of models have been used: rats, mice, Caenorhabditis elegans, fish (zebrafish), Drosophila melanogaster and, in a lesser extent, human studies (Table 4). Each model has its advantages and limitations, but all provide a great deal of information that helps us to conclude facts. Within all these models, rats and mice may be the most used, but the one that generates the most interest is the human model, since it provides real data when it comes to human applications.

Table 4. In vivo studies regarding silver nanoparticles effects at gut level and microbiota, organs and tissues.

\begin{tabular}{|c|c|c|c|}
\hline Model & Study Design & Main Results & Reference \\
\hline C57BL/6N mice & $\begin{array}{c}\text { Ag-NPs } 29,3 \mathrm{~nm} \text { Dose: } \\
100 \mathrm{mg} / \mathrm{kg}, 500 \mathrm{mg} / \mathrm{kg} \text { or } \\
1000 \mathrm{mg} / \mathrm{kg}\end{array}$ & $\begin{array}{l}\text { The production of significant alterations of } \\
\text { selective genes in the caudate, frontal cortex } \\
\text { and hippocampus of mice was observed } \\
\text { after exposure to the nanoparticles. The } \\
\text { data concluded that nanoparticles can } \\
\text { produce neurotoxicity by generating } \\
\text { oxidative stress. }\end{array}$ & [101] \\
\hline $\begin{array}{l}\text { Sprague-Dawley } \\
\text { rats }\end{array}$ & $\begin{array}{l}\text { Ag-NPs } 60 \mathrm{~nm} ; 28 \text { days Four } \\
\text { groups (10 rats in each } \\
\text { group): vehicle control, } \\
\text { low-dose group ( } 30 \mathrm{mg} / \mathrm{kg}) \text {, } \\
\text { middle-dose group }(300 \\
\mathrm{mg} / \mathrm{kg}) \text {, and high-dose } \\
\text { group }(1000 \mathrm{mg} / \mathrm{kg})\end{array}$ & $\begin{array}{l}\text { A dose-dependent increased accumulation } \\
\text { of Ag-NPs was observed in the lamina } \\
\text { propria in both the small and large intestine, } \\
\text { and also in the tip of the upper villi in the } \\
\text { ileum and protruding surface of the fold in } \\
\text { the colon. Rats that consumed } \\
\text { nanoparticles also released more anormal } \\
\text { mucus in the crypt lumen and ileal lumen } \\
\text { and there was also detachment of cells at } \\
\text { the tip of the villi. }\end{array}$ & [102] \\
\hline F344 rats & $\begin{array}{l}\text { Ag-NPs } 56 \mathrm{~nm} ; 13 \text { weeks } \\
\text { Four groups (10 rats in each } \\
\text { group): vehicle control, } \\
\text { low-dose }(30 \mathrm{mg} / \mathrm{kg}), \\
\text { middle-dose }(125 \mathrm{mg} / \mathrm{kg}) \\
\text { and high-dose }(500 \mathrm{mg} / \mathrm{kg}) .\end{array}$ & $\begin{array}{l}\text { Significant dose-dependent changes were } \\
\text { found in alkaline phosphatase and } \\
\text { cholesterol, indicating that exposure to } \\
\text { more than } 125 \mathrm{mg} / \mathrm{kg} \text { of silver nanoparticles } \\
\text { may result in slight liver damage. } \\
\text { Histopathologic examination revealed a } \\
\text { higher incidence of bile-duct hyperplasia, } \\
\text { with or without necrosis. There was also a } \\
\text { dose-dependent accumulation of silver in } \\
\text { all tissues examined. }\end{array}$ & [103] \\
\hline Mice & $\begin{array}{c}\text { Ag-NPs 3-20 nm; } 21 \text { days } \\
\text { Daily dose: 5, 10, } 15 \mathrm{y} \\
20 \mathrm{mg} / \mathrm{kg}\end{array}$ & $\begin{array}{l}\text { Mice treated with a dose of } 10 \mathrm{mg} / \mathrm{kg} \\
\text { showed great weight loss. It was found that } \\
\text { Ag-NPs damaged the microvilli of } \\
\text { epithelial cells and intestinal glands. This } \\
\text { may be the cause of weight loss due to } \\
\text { intestinal malabsorption. }\end{array}$ & [104] \\
\hline Wistar rats & $\begin{array}{l}\text { Ag-NPs } 10 \mathrm{~nm} ; 14 \text { days } \\
\text { Daily dose: } 0.02 \mathrm{mg} / \mathrm{kg}\end{array}$ & $\begin{array}{l}\text { Ag-NPs intake produced a synaptic } \\
\text { degeneration and potential neuronal cell } \\
\text { death due to alterations in synaptic } \\
\text { structures and reduced levels of proteins } \\
\text { associated with these structures }\end{array}$ & [105] \\
\hline $\begin{array}{l}\text { Sprague-Dawley } \\
\text { rats }\end{array}$ & $\begin{array}{l}\text { Ag-NPs 3-10 nm (98.7\%), } \\
10-30 \mathrm{~nm}(1.3 \%) ; 14 \text { days } \\
\text { Daily dose: } 1 \mathrm{mg} / \mathrm{kg} \text { or } \\
10 \mathrm{mg} / \mathrm{kg} \text { Three groups } \\
\text { (6 rats in each group): } \\
\text { control group, low-dose } \\
\text { group ( } 1 \mathrm{mg} / \mathrm{kg}), \text { high-dose } \\
\text { group }(10 \mathrm{mg} / \mathrm{kg})\end{array}$ & $\begin{array}{l}\text { After ingestion of Ag-NPs, neuron } \\
\text { shrinkage, cytoplasmic or foot } \\
\text { inflammation of the astrocytes and } \\
\text { extravascular lymphocytes occurred. This } \\
\text { led to the conclusion that Ag-NPs can } \\
\text { induce neuronal degeneration and swelling } \\
\text { of astrocytes even with oral exposure at low } \\
\text { doses. }\end{array}$ & [106] \\
\hline
\end{tabular}


Table 4. Cont.

\begin{tabular}{|c|c|c|c|}
\hline Model & Study Design & Main Results & Reference \\
\hline $\begin{array}{l}\text { C57BL/6NCrl } \\
\text { mice }\end{array}$ & $\begin{array}{l}\text { Ag-NPs } 110 \mathrm{~nm} \text { and } 20 \mathrm{~nm} \\
\text { (PVP), } 110 \mathrm{~nm} \text { and } 20 \mathrm{~nm} \\
\text { (Citrate); } 28 \text { days } \\
\text { Daily dose: } 10 \mathrm{mg} / \mathrm{kg}\end{array}$ & $\begin{array}{l}\text { None of the nanoparticles tested caused } \\
\text { alterations in the structure or diversity of } \\
\text { the intestinal microbiota of the mice. }\end{array}$ & [107] \\
\hline $\begin{array}{l}\text { Sprague-Dawley } \\
\text { rats }\end{array}$ & $\begin{array}{l}\text { Ag-NPs 10, } 75 \text { and } 100 \mathrm{~nm} ; \\
13 \text { weeks } \\
\text { Daily dose: } 9,18 \text { and } \\
36 \mathrm{mg} / \mathrm{kg} \text { twice a day }\end{array}$ & $\begin{array}{l}\text { It was possible to observe how the } \\
\text { nanoparticles produced changes in the } \\
\text { intestinal microbiota of the rats. There was } \\
\text { an increase in Gram-negative bacteria. } \\
\text { Exposure to smaller Ag-NPs resulted in a } \\
\text { decrease in Lactobacillus spp. and the } \\
\text { Firmicutes phyla. }\end{array}$ & [108] \\
\hline $\begin{array}{l}\text { Sprague-Dawley } \\
\text { rats }\end{array}$ & $\begin{array}{l}\text { Ag-NPs } 12 \mathrm{~nm} \text {; single } \\
\text { exposure and multiple } \\
\text { exposures over } 30 \text { days Daily } \\
\text { doses: } 2000 \text { and } 250 \mathrm{mg} / \mathrm{kg} \\
\text { for single and multiple } \\
\text { administrations, } \\
\text { respectively. }\end{array}$ & $\begin{array}{l}\text { Single and multiple administrations } \\
\text { resulted in silver accumulation in the liver, } \\
\text { kidneys, spleen, stomach, and small } \\
\text { intestine. But, concentrations of silver } \\
\text { detected in tissues were far smaller than the } \\
\text { administered doses ( }<99 \%) \text {, indicating its } \\
\text { efficient excretion from the organism. }\end{array}$ & [109] \\
\hline BALB/C mice & $\begin{array}{l}\text { Ag-NPs } 294 \text { nm (NanoAg1) } \\
\text { and } 122 \text { nm (NanoAg 2); } \\
3 \text { days } \\
\text { Daily dose: } 100 \mu \mathrm{L} \\
\text { suspension }\end{array}$ & $\begin{array}{l}\text { The administration of NanoAg1 increased } \\
\text { the number of Clostridium perfringens and } \\
\text { Escherichia coli and decreased that of } \\
\text { Lactobacillus spp., But the results were not } \\
\text { significant. NanoAg2 acted in reverse. It } \\
\text { could also be seen how nanoparticle } \\
\text { suspensions reversed a severe colonic } \\
\text { lesion in mice. }\end{array}$ & [110] \\
\hline Mice & $\begin{array}{l}\text { Ag-NPs } 55.17 \mathrm{~nm} ; 28 \text { days } \\
\text { Doses: } 0 \text { (control), 11.4, } 114 \\
\text { and } 1140 \mu \mathrm{g} \mathrm{Ag-NP/kg}\end{array}$ & $\begin{array}{l}\text { In this work, an increase in the } \\
\text { Firmicutes/Bacteroidetes ratio was } \\
\text { observed, similar to that described in } \\
\text { studies of obesity and inflammatory } \\
\text { diseases. }\end{array}$ & [111] \\
\hline $\begin{array}{l}\text { Fish (Piaractus } \\
\text { mesopotamicus) }\end{array}$ & $\begin{array}{c}\text { Ag-NPs } 50 \mathrm{~nm} ; 24 \mathrm{~h} \\
\text { Dose: } 0 \text { (control), } 2.5,10 \text {, and } \\
25 \mu \mathrm{g} \mathrm{Ag-NPs/L}\end{array}$ & $\begin{array}{l}\text { More silver accumulated in the brain than } \\
\text { in gills and liver at all concentrations. There } \\
\text { was also an increase in oxidative stress, as } \\
\text { well as damage to the enterocytes in fish } \\
\text { exposed to higher concentrations. }\end{array}$ & [112] \\
\hline Zebrafish & $\begin{array}{l}\text { Ag-NPs } 58.6 \mathrm{~nm} ; 14 \text { days } \\
\text { Dose: } 500 \mathrm{mg} / \mathrm{kg} \text { twice a day }\end{array}$ & $\begin{array}{l}\text { Despite not finding lesions in the integrity } \\
\text { of the intestinal epithelium, in this study it } \\
\text { was observed that Ag-NPs decreased to a } \\
\text { non-detectable level to beneficial bacterial } \\
\text { populations of fish. }\end{array}$ & [113] \\
\hline Zebrafish & $\begin{array}{l}\text { Ag-NPs } 10,40 \text { and } 100 \mathrm{~nm} ; \\
4 \text { days } \\
\text { Dose: } 1,5,10,50,100,150 \mathrm{y} \\
200 \mathrm{ppm}\end{array}$ & $\begin{array}{l}\text { It was observed that the salts and cations of } \\
\text { the medium decreased the dissolution of } \\
\text { the silver, thus limiting its action. Ag-NPs } \\
\text { with a size of } 10 \text { and } 100 \mathrm{~nm} \text { caused } \\
\text { developmental defects in the muscles and } \\
\text { intestine of the embryo, while those of } 40 \\
\text { nm produced lethal effects. }\end{array}$ & [114] \\
\hline Zebrafish & $\begin{array}{c}\text { Ag-NPs } 20 \text { and } 100 \mathrm{~nm} ; 96 \mathrm{~h} \\
\text { Dose: } 0.61,1.07,0.67 \text {, and } \\
1.28 \mathrm{mg} / \mathrm{L}\end{array}$ & $\begin{array}{l}\text { The coating of the nanoparticles increased } \\
\text { the survival rate of the fish compared to the } \\
\text { control. It was also observed that the } \\
\text { smaller Ag-NPs were more lethal than the } \\
100 \mathrm{~nm} \text {. More nanoparticles accumulated in } \\
\text { the intestines than in the gills. }\end{array}$ & [115] \\
\hline
\end{tabular}


Table 4. Cont.

\begin{tabular}{|c|c|c|c|}
\hline Model & Study Design & Main Results & Reference \\
\hline $\begin{array}{c}\text { Caenorhabditis } \\
\text { elegans }\end{array}$ & Ag-NPs $79 \mathrm{~nm}$ & $\begin{array}{l}\text { The effect of silver nanoparticles for } 10 \\
\text { generations of the nematode was studied. } \\
\text { From the second a pronounced sensitization } \\
\text { to the nanomaterial was observed. }\end{array}$ & [116] \\
\hline $\begin{array}{l}\text { Caenorhabditis } \\
\text { elegans }\end{array}$ & $\begin{array}{c}\text { Ag-NPs } 25 \text { and } 75 \mathrm{~nm} ; 12 \mathrm{~h} \\
\text { Dose: } 5 \mathrm{mg} / \mathrm{L}\end{array}$ & $\begin{array}{l}\text { Exposure of E. coli to the nanoparticles and } \\
\text { of the nematode to E. coli induced } \\
\text { reproductive toxicity, as well as } \\
\text { neurotoxicity. }\end{array}$ & [117] \\
\hline $\begin{array}{c}\text { Caenorhabditis } \\
\text { elegans }\end{array}$ & $\begin{array}{c}\text { Ag-NPs }<100 ; 40 \mathrm{~h} \\
\text { Dose: } 0,1,3 \text {, and } 5 \mathrm{mg} / \mathrm{kg}\end{array}$ & $\begin{array}{l}\text { Different silver nanomaterials induce } \\
\text { growth inhibition and reproductive toxicity } \\
\text { when the soil is found at a concentration of } \\
\geq 5 \mathrm{mg} / \mathrm{kg} \text {. }\end{array}$ & [118] \\
\hline $\begin{array}{l}\text { Caenorhabditis } \\
\text { elegans }\end{array}$ & $\mathrm{Ag}-\mathrm{NPs} \approx 69 \mathrm{~nm}$ & $\begin{array}{l}\text { Factors that increased sensitivity and } \\
\text { reproductive toxicity from the second } \\
\text { generation could not be verified. Therefore, } \\
\text { long-term risk cannot be assessed and other } \\
\text { inheritance mechanisms, such as } \\
\text { epigenetics, may be at play in } \\
\text { multigenerational reproductive toxicity. }\end{array}$ & [119] \\
\hline $\begin{array}{l}\text { Drosophila } \\
\text { melanogaster }\end{array}$ & $\begin{array}{c}\text { Dose: } 10-100 \mu \mathrm{g} \mathrm{Ag} / \mathrm{mL} \\
\text { (accute intake) and } 5 \mu \mathrm{g} \\
\mathrm{Ag} / \mathrm{mL} \text { (chronic exposure) }\end{array}$ & $\begin{array}{l}\text { After the acute intake, a significant toxic } \\
\text { effect was observed at the concentration of } \\
20 \mu \mathrm{g} / \mathrm{mL} \text { and } 50 \% \text { of the flies could not } \\
\text { complete their development cycle. In the } \\
\text { case of the chronic exposure in } 8 \\
\text { generations, a decrease in fertility was } \\
\text { observed in the first three generations, after } \\
\text { which it returned to normal. }\end{array}$ & {$[120]$} \\
\hline $\begin{array}{l}\text { Drosophila } \\
\text { melanogaster }\end{array}$ & $\begin{array}{c}\text { Ag-NPs 5-22 nm } \\
\text { Dose: } 10,50,100,200 \mathrm{~g} / \mathrm{mL}\end{array}$ & $\begin{array}{l}\text { All nanoparticles tested (synthesized from } \\
\text { different natural extracts) significantly } \\
\text { reduced the number of hatched larvae. } \\
\text { In addition, those synthesized from } \\
\text { mulberry, fig and olive produced a high } \\
\text { mortality of larvae and adults. }\end{array}$ & {$[121]$} \\
\hline $\begin{array}{l}\text { Drosophila } \\
\text { melanogaster }\end{array}$ & $\begin{array}{l}\text { Ag-NPs } 20-100 \mathrm{~nm} ; 3 \\
10 \text { and } 30 \text { days } \\
\text { Dose: } 5,25,50 \text { and } 250 \mu \mathrm{g} \\
\text { Ag/mL }\end{array}$ & $\begin{array}{l}\text { The effect of Ag-NPs depends on the dose } \\
\text { and the stage of development of the flies. } \\
\text { In general it alters the ability to lay eggs, } \\
\text { decrease the size of the ovary and decrease } \\
\text { survival and longevity. }\end{array}$ & {$[122]$} \\
\hline $\begin{array}{l}\text { Drosophila } \\
\text { melanogaster }\end{array}$ & $\begin{array}{c}\text { Ag-NPs } 3.44 \mathrm{~nm} ; 10 \text { days } \\
\text { Dose: } 0.016,0.08,0.4,1 \mathrm{y} \\
2 \mathrm{mM}\end{array}$ & $\begin{array}{l}\text { The } 10 \mathrm{nM} \text { dose was completely toxic. } \\
\text { Despite this, depigmentation was observed } \\
\text { at all concentrations. Significant levels of } \\
\text { intracellular ROS and DNA damage were } \\
\text { also observed. }\end{array}$ & {$[123]$} \\
\hline Humans & $\begin{array}{c}\text { Volunteers: } 60 \\
\text { Ag-NPs 5-10 nm (10 ppm) or } \\
\text { 25-40 nm (32 ppm) } \\
\text { Study 1: } 10 \text { ppm with 3, 7, } \\
\text { and 14 day time periods } \\
\text { Study 2: } 32 \text { ppm for } 14 \text { days } \\
\text { Daily dose: } 100 \mu \mathrm{g} / \text { day for } \\
10 \text { ppm, and } 480 \mu \mathrm{g} / \text { day for } \\
32 \mathrm{ppm}\end{array}$ & $\begin{array}{l}\text { No significant changes were observed in } \\
\text { metabolism, hematology, urine, physical } \\
\text { findings, sputum morphology or changes } \\
\text { in images. Nor were statistically significant } \\
\text { changes detected in the markers of } \\
\text { hydrogen peroxide production or } \\
\text { peroxiredoxin protein expression. Instead, } \\
\text { silver could be detected in human serum. }\end{array}$ & {$[124]$} \\
\hline
\end{tabular}

Regarding the findings with rat and mice, several studies have been carried out to evaluate the effect of these nanoparticles on the gastrointestinal tract. An abnormal mucus composition of the intestines of the animals was observed, as well as pigmentation of the villi and discharge of mucus 
granules $[102,103,109]$. In another study, it was discovered that Ag-NP damaged the microvilli of epithelial cells and intestinal glands in rats, thus decreasing the intestinal absorption of nutrients [104]. In the study by van den Brule et al. [111], by using Next Generation Sequencing (NGS), they observed how the intake of dietary doses Ag-NPs during $28 \mathrm{~d}$ did not significantly alter, in a dose-dependent manner, either the uniformity of the intestinal microbiota or populations in rats. But they could see an increase in the relationship between Firmicutes and Bacteroidetes phyla. Human and mouse gut microbiota are very similar at the phylum level, but not at the genera or species level; however, at least at the phylum level, these results could be extrapolated to humans. It was also discovered that the consumption of Ag-NPs modified the values of cholesterol and alkaline phosphatase in rats, which indicated that exposure to these nanoparticles could cause mild liver damage [103]. Silver nanoparticles are also easily able to cross the tight junction of the blood-brain barrier (BBB); therefore, they can be considered as neurotoxic. Rahman et al. [101] showed a neurotoxic effect induced by oxidative stress of Ag-NPs in three regions of the brain, including the caudate nucleus, the frontal cortex and the hippocampus of adult mice. In addition, another study showed that Ag-NPs produced neuronal degeneration and inflammation of astrocytes in the rat brain due to a low dose of exposure by oral and intragastric administration $[105,106]$.

There are studies with other animal models like fishes. After exposure of fish at Ag-NPs concentrations of $2.5,10$, and $25 \mu \mathrm{g} / \mathrm{L}$ for $24 \mathrm{~h}$, it was observed that the accumulation of silver in the brain was greater than in the liver and gills. In addition, fish that were exposed to the highest concentrations showed alterations in markers of oxidative stress [112]. In another study, various sizes of Ag-NPs coated with gum arabic (10, 40 and $100 \mathrm{~nm})$ were used. Zebrafish embryos were exposed to various concentrations of these nanoparticles for 4 days and only an increase in lethality was observed with the $40 \mathrm{~nm}$ nanoparticles. This could be because of the retention of silver in the intestine depends on the particle size and the agglomerates [114]. In the same line is the work of Liu et al. [115], in which they demonstrated that the particle size is more influenced by the toxicity of Ag-NPs than the coating. Ag-NPs of small size $(20 \mathrm{~nm})$ and with citrate coating were more toxic and the toxic effect was greater in the intestine than in the gills or muscles. Merrifield et al. [113] showed, in adult zebrafish, that exposure to silver nanoparticles ( $500 \mathrm{mg} / \mathrm{kg}$ food) for 14 days had no effect on the richness and diversity of the microbiota. Similarly, Wilding et al. [107] found that the oral administration of silver nanoparticles of two different sizes (20 and $110 \mathrm{~nm})$ and with two different coatings (PVP and citrate) for 28 days $(10 \mathrm{mg} / \mathrm{kg}$ bw/day) did not change the diversity of the gut microbiome in mice. In another study, the effect of Ag-NPs in mouse models with inflammatory bowel disease was evaluated. A decrease in inflammation and a positive modulation of the gut microbiota could be observed [110]. By contrast, another study on rats fed twice-daily with oral silver nanoparticles for 13 weeks at various doses $(9,18$ and $36 \mathrm{mg} / \mathrm{kg}$ bw/day) reported a general increase in the levels of Gram negative bacteria, and a decrease in the levels of Firmicutes [108]. It is important to note that there are differences between the human and zebrafish and rodent microbiome. Moreover, differences during gut transit and the interactions with the composition of the food matrix between animals and humans can affect nanomaterial properties in a different way during digestive transit and their putative effects.

There are also studies with Caenorhabditis elegans. In one of them, it was observed how the reactive oxygen species in the nematode increased when exposed to E. coli contaminated with Ag-NPs. They also increased reproductive toxicity and neurotoxicity [117]. Moon et al. [118] showed that the presence of different silver nanomaterials (including nanoparticles) in the soil decreased the growth and reproduction of C. elegans. Similarly, in another study, the hereditary reproductive toxicity produced by Ag-NPs in C. elegans was demonstrated and it was observed that this toxicity contributed to inducing germline mutations [116,119].

Finally, another of the most used non-human models is Drosophila melanogaster. In one of the studies, the larvae were fed with silver nanoparticles, which were able to reach the intestinal barrier. This was demonstrated by analyzing the increase in intracellular ROS [123]. Reproductive toxicity was 
also evaluated in this model. It was observed that exposure of adult specimens to Ag-NPs significantly affected the ability to lay eggs along with a deteriorated ovarian growth [121,122]. In a study of acute and chronic exposure, it was observed that the effect of a solution of Ag-NPs at a concentration of $20 \mathrm{ug} / \mathrm{mL} \mathrm{50 \%} \mathrm{of} \mathrm{the} \mathrm{larvae} \mathrm{did} \mathrm{not} \mathrm{end} \mathrm{their} \mathrm{development} \mathrm{cycle.} \mathrm{In} \mathrm{addition,} \mathrm{after} \mathrm{chronic} \mathrm{exposure} \mathrm{to}$ an Ag-Nps solution of $5 \mathrm{ug} / \mathrm{mL}$, it was shown that after three generations, the flies adapted to silver, recovering the fecundity lost in the first three [120].

As can be seen in the aforementioned paragraphs, Ag-NPs have been shown to have toxic effects to both in in vitro and in vivo models; however, there is a limited number of studies that reported the impacts of Ag-NPs on human health. One of them is the one carried out by Munger et al. [124]. A total of 60 healthy subjects ingested nanoparticles at concentrations of 10 and 32 ppm (Ag-NPs size: 5-10 nm) for 14 days. No significant changes were detected in the morphology of heart, lungs and other organs, nor in the reactive oxygen species or in the generation of proinflammatory cytokines. Nor did significant changes in metabolic measures appear in the conditions studied. The authors stressed the need to evaluate the effects of longer-term exposure.

Because of the increased potential for consumer exposure to Ag NP, it appeared urgent to assess the possible impact on the gut microbiota and on human health. As reviewed, few studies have investigated this issue and none are conclusive. The differences of results between studies could be related to the techniques used to analyze the microbiota. Moreover, it is difficult to make a comparison between studies published today because different sizes, shapes and concentrations of nanoparticles have been used. As a suggestion, future experiments should consider validated standards to ensure more comparable results and thus, make more reliable conclusions. Moreover, the transfer of results from animals to humans could be improved with the use of "humanized" animals by inoculation of human gut microbiota as well as by investigations conducted with longer exposure durations to better mimic human exposure scenarios.

\section{Conclusions and Future Perspectives}

Nanotechnology and specifically, silver nanoparticles, have a promising future ahead in the field of food. Silver nanoparticles have demonstrated extensive antimicrobial activity against foodborne pathogens as well as great effectiveness when they are incorporated into different types of packaging. Today, most studies focusing on the use of Ag-NPs in packaging are at the laboratory level and in most countries, are not allowed. In the European Union, in particular, more data are necessary to define the regulation of their employment. Therefore, investigation of the use of nanoparticles as a food additive is needed, as well as the evaluation of their effect on consumer health, since there are no long-term studies that assess the real concerns of their consumption. Very few studies have focused on the relationships between nanoparticles and oral microbiota, and, in the same way, effects of silver nanoparticles on the composition of the intestinal microbiota and the consequences on their metabolic activity are largely unknown. The range of models and diverse experimental conditions, such as in vitro, ex vivo and in vivo approaches, animal models and control conditions, make it even more difficult to compare the results and draw final conclusions. A crucial aspect for in vitro studies is to take care to incorporate the changing physiochemical properties of silver nanoparticles during transit of the gastrointestinal tract in the study design. It is also necessary to continue studying the different types of silver nanoparticles including form, size distribution as well as dose and modes of administration/exposure of them to state detrimental effects on health. Finally, the difficulties involved in the evaluation in vivo of the effects of ingested nanoparticles in the gut, due to differences between species (rodents vs. humans), may also be highlighted. Probable variability between individuals, not only in terms of the composition, but also in terms of the functional metabolic properties of the microbiota, should also be taken into account along with host physiological characteristics and environmental factors. In conclusion, given their potential and wide properties against foodborne pathogens, research into silver nanoparticles is of great interest for the food industry but is not exempt from difficulties that must be resolved in order to certify the safety of their use. 
Author Contributions: Investigation and evaluation of published studies, I.Z.-P., C.C. and M.V.M.-A., Contributing in writing the manuscript, I.Z.-P., C.C., B.B. and M.V.M.-A., Designing of figures and tables, I.Z.-P.; C.C.; Supervision of the study, M.V.M.-A. All authors have read and agreed to the published version of the manuscript.

Funding: Research in our lab is funded by Grants AGL2015-64522-C2-R (Spanish Ministry of Economy and Competitiveness) and ALIBIRD-CM 2020 P2018/BAA-4343 (Comunidad de Madrid). I.Z.-P. thanks BES-2016-077980 contract.

Conflicts of Interest: The authors declare no conflict of interest.

\section{References}

1. WHO. Food Safety. 2019. Available online: https://www.who.int/news-room/fact-sheets/detail/food-safety (accessed on 1 October 2019).

2. Bari, M.L.; Yeasmin, S. Chapter 8-Foodborne Diseases and Responsible Agents. In Food Safety and Preservation; Grumezescu, A.M., Holban, A.M., Eds.; Academic Press: Cambridge, MA, USA, 2018; pp. 195-229.

3. Malhotra, B.; Keshwani, A.; Kharkwal, H. Antimicrobial food packaging: Potential and pitfalls. Front. Microbiol. 2015, 6, 611. [CrossRef] [PubMed]

4. Perez-Esteve, E.; Bernardos, A.; Martinez-Manez, R.; Barat, J.M. Nanotechnology in the development of novel functional foods or their package. An overview based in patent analysis. Recent Pat. Food Nutr. Agric. 2013, 5, 35-43. [CrossRef] [PubMed]

5. Monge, M.; Moreno-Arribas, M.V. Applications of Nanotechnology in Wine Production and Quality and Safety Control. In Wine: Safety, Consumer Preferences, and Health; Moreno-Arribas, M.V., Bartolomé, B., Eds.; Springer Life Sciences Publisher: New York, NY, USA, 2016; pp. 51-69.

6. Rao, C.N.R.; Cheetham, A.K. Science and technology of nanomaterials: Current status and future prospects. J. Mater. Chem. 2001, 11, 2887-2894. [CrossRef]

7. Edmundson, M.; Thanh, N.T.; Song, B. Nanoparticles based stem cell tracking in regenerative medicine. Theranostics 2013, 3, 573-582. [CrossRef] [PubMed]

8. Silva, L.P.; Silveira, A.P.; Bonatto, C.C.; Reis, I.G.; Milreu, P.V. Chapter 26-Silver Nanoparticles as Antimicrobial Agents: Past, Present, and Future. In Nanostructures for Antimicrobial Therapy; Ficai, A., Grumezescu, A.M., Eds.; Elsevier: Amsterdam, The Netherlands, 2017; pp. 577-596.

9. Rafique, M.; Sadaf, I.; Rafique, M.S.; Tahir, M.B. A review on green synthesis of silver nanoparticles and their applications. Artif. Cells Nanomed. Biotechnol. 2017, 45, 1272-1291. [CrossRef] [PubMed]

10. Abbaszadegan, A.; Ghahramani, Y.; Gholami, A.; Hemmateenejad, B.; Dorostkar, S.; Nabavizadeh, M.; Sharghi, H. The Effect of Charge at the Surface of Silver Nanoparticles on Antimicrobial Activity against Gram-Positive and Gram-Negative Bacteria: A Preliminary Study. J. Nanomater. 2015, 2015, 8. [CrossRef]

11. Jo, D.H.; Kim, J.H.; Lee, T.G.; Kim, J.H. Size, surface charge, and shape determine therapeutic effects of nanoparticles on brain and retinal diseases. Nanomed. Nanotechnol. Biol. Med. 2015, 11, 1603-1611. [CrossRef]

12. Gordienko, M.G.; Palchikova, V.V.; Kalenov, S.V.; Belov, A.A.; Lyasnikova, V.N.; Poberezhniy, D.Y.; Chibisova, A.V.; Sorokin, V.V.; Skladnev, D.A. Antimicrobial activity of silver salt and silver nanoparticles in different forms against microorganisms of different taxonomic groups. J. Hazard. Mater. 2019, 378, 120754. [CrossRef]

13. Singh, J.; Dutta, T.; Kim, K.H.; Rawat, M.; Samddar, P.; Kumar, P. ‘Green' synthesis of metals and their oxide nanoparticles: Applications for environmental remediation. J. Nanobiotechnol. 2018, 16, 84. [CrossRef]

14. Ren, Y.Y.; Yang, H.; Wang, T.; Wang, C. Bio-synthesis of silver nanoparticles with antibacterial activity. Mater. Chem. Phys. 2019, 235, 121746. [CrossRef]

15. Navarro Gallón, S.M.; Alpaslan, E.; Wang, M.; Larese-Casanova, P.; Londoño, M.E.; Atehortúa, L.; Pavón, J.J.; Webster, T.J. Characterization and study of the antibacterial mechanisms of silver nanoparticles prepared with microalgal exopolysaccharides. Mat. Sci. Eng. C Mater. 2019, 99, 685-695. [CrossRef] [PubMed]

16. Pal, S.; Tak, Y.K.; Song, J.M. Does the antibacterial activity of silver nanoparticles depend on the shape of the nanoparticle? A study of the Gram-negative bacterium Escherichia coli. Appl. Environ. Microbiol. 2007, 73, 1712-1720. [CrossRef] [PubMed]

17. Sadeghi, B.; Garmaroudi, F.S.; Hashemi, M.; Nezhad, H.R.; Nasrollahi, A.; Ardalan, S.; Ardalan, S. Comparison of the anti-bacterial activity on the nanosilver shapes: Nanoparticles, nanorods and nanoplates. Adv. Powder Technol. 2012, 23, 22-26. [CrossRef] 
18. Lu, W.; Yao, K.; Wang, J.; Yuan, J. Ionic liquids-water interfacial preparation of triangular Ag nanoplates and their shape-dependent antibacterial activity. J. Colloid Interf. Sci. 2015, 437, 35-41. [CrossRef] [PubMed]

19. Lu, Z.; Rong, K.; Li, J.; Yang, H.; Chen, R. Size-dependent antibacterial activities of silver nanoparticles against oral anaerobic pathogenic bacteria. J. Mater. Sci. Mater. Med. 2013, 24, 1465-1471. [CrossRef] [PubMed]

20. Khurana, C.; Vala, A.K.; Andhariya, N.; Pandey, O.P.; Chudasama, B. Antibacterial activity of silver: The role of hydrodynamic particle size at nanoscale. J. Biomed. Mater. Res. A 2014, 102, 3361-3368. [CrossRef] [PubMed]

21. Ivask, A.; Kurvet, I.; Kasemets, K.; Blinova, I.; Aruoja, V.; Suppi, S.; Vija, H.; Kakinen, A.; Titma, T.; Heinlaan, M.; et al. Size-dependent toxicity of silver nanoparticles to bacteria, yeast, algae, crustaceans and mammalian cells in vitro. PLOS ONE 2014, 9, e102108. [CrossRef]

22. Qing, Y.; Cheng, L.; Li, R.; Liu, G.; Zhang, Y.; Tang, X.; Wang, J.; Liu, H.; Qin, Y. Potential antibacterial mechanism of silver nanoparticles and the optimization of orthopedic implants by advanced modification technologies. Int. J. Nanomed. 2018, 13, 3311-3327. [CrossRef]

23. Duran, N.; Duran, M.; de Jesus, M.B.; Seabra, A.B.; Favaro, W.J.; Nakazato, G. Silver nanoparticles: A new view on mechanistic aspects on antimicrobial activity. Nanomed. Nanotechnol. 2016, 12, 789-799. [CrossRef]

24. Gugala, N.; Lemire, J.; Chatfield-Reed, K.; Yan, Y.; Chua, G.; Turner, R.J. Using a chemical genetic screen to enhance our understanding of the antibacterial properties of silver. Genes 2016, 9, 344. [CrossRef]

25. Dakal, T.C.; Kumar, A.; Majumdar, R.S.; Yadav, V. Mechanistic basis of antimicrobial actions of silver nanoparticles. Front. Microbiol. 2016, 7, 1831. [CrossRef] [PubMed]

26. Ghosh, S.; Patil, S.; Ahire, M.; Kitture, R.; Kale, S.; Pardesi, K.; Cameotra, S.S.; Bellare, J.; Dhavale, D.D.; Jabgunde, A.; et al. Synthesis of silver nanoparticles using Dioscorea bulbifera tuber extract and evaluation of its synergistic potential in combination with antimicrobial agents. Int. J. Nanomed. 2012, 7, 483-496.

27. Yue, Z.G.; Wei, W.; Lv, P.P.; Yue, H.; Wang, L.Y.; Su, Z.G.; Ma, G.H. Surface charge affects cellular uptake and intracellular trafficking of chitosan-based nanoparticles. Biomacromolecules 2011, 12, 2440-2446. [CrossRef] [PubMed]

28. Salas-Orozco, M.; Niño-Martínez, N.; Martínez-Castañón, G.; Torres Méndez, F.; Compean Jasso, M.E.; Ruiz, F. Mechanisms of resistance to silver nanoparticles in endodontic bacteria: A literature review. J. Nanomater. 2019, 2019, 11. [CrossRef]

29. Zodrow, K.; Brunet, L.; Mahendra, S.; Li, D.; Zhang, A.; Li, Q.; Alvarez, P.J. Polysulfone ultrafiltration membranes impregnated with silver nanoparticles show improved biofouling resistance and virus removal. Water Res. 2009, 43, 715-723. [CrossRef] [PubMed]

30. Dankovich, T.A.; Gray, D.G. Bactericidal paper impregnated with silver nanoparticles for point-of-use water treatment. Environ. Sci. Technol. 2011, 45, 1992-1998. [CrossRef] [PubMed]

31. Kanmani, P.; Lim, S.T. Synthesis and structural characterization of silver nanoparticles using bacterial exopolysaccharide and its antimicrobial activity against food and multidrug resistant pathogens. Process Biochem. 2013, 48, 1099-1106. [CrossRef]

32. Deus, D.; Kehrenberg, C.; Schaudien, D.; Klein, G.; Krischek, C. Effect of a nano-silver coating on the quality of fresh turkey meat during storage after modified atmosphere or vacuum packaging. Poultr. Sci. 2017, 96, 449-457. [CrossRef]

33. Silvan, J.M.; Zorraquin-Pena, I.; Gonzalez de Llano, D.; Moreno-Arribas, M.V.; Martinez-Rodriguez, A.J. Antibacterial activity of glutathione-stabilized silver nanoparticles against Campylobacter multidrug-resistant strains. Front. Microbiol. 2018, 9, 458. [CrossRef]

34. Wu, Z.; Huang, X.; Li, Y.C.; Xiao, H.; Wang, X. Novel chitosan films with laponite immobilized Ag nanoparticles for active food packaging. Carbohydr. Polym. 2018, 199, 210-218. [CrossRef]

35. Chandhru, M.; Logesh, R.; Rani, S.K.; Ahmed, N.; Vasimalai, N. One-pot green route synthesis of silver nanoparticles from jack fruit seeds and their antibacterial activities with escherichia coli and salmonella bacteria. Biocatal. Agric. Biotechnol. 2019, 20, 101241. [CrossRef]

36. Du, J.; Hu, Z.; Yu, Z.; Li, H.; Pan, J.; Zhao, D.; Bai, Y. Antibacterial activity of a novel Forsythia suspensa fruit mediated green silver nanoparticles against food-borne pathogens and mechanisms investigation. Mater. Sci. Eng. C 2019, 102, 247-253. [CrossRef] [PubMed]

37. Mathew, S.; Snigdha, S.; Mathew, J.; Radhakrishnan, E.K. Biodegradable and active nanocomposite pouches reinforced with silver nanoparticles for improved packaging of chicken sausages. Food Packag. Shelf Life 2019, 19, 155-166. [CrossRef] 
38. Yu, Z.; Wang, W.; Kong, F.; Lin, M.; Mustapha, A. Cellulose nanofibril/silver nanoparticle composite as an active food packaging system and its toxicity to human colon cells. Int. J. Biol. Macromol. 2019, 129, 887-894. [CrossRef]

39. Singh, T.; Shukla, S.; Kumar, P.; Wahla, V.; Bajpai, V.K. Application of Nanotechnology in Food Science: Perception and Overview. Front. Microbiol. 2017, 8, 1501. [CrossRef]

40. Fondevila, M.; Herrer, R.; Casallas, M.C.; Abecia, L.; Ducha, J.J. Silver nanoparticles as a potential antimicrobial additive for weaned pigs. Anim. Feed Sci. Tech. 2009, 150, 259-269. [CrossRef]

41. Pineda, L.; Chwalibog, A.; Sawosz, E.; Lauridsen, C.; Engberg, R.; Elnif, J.; Hotowy, A.; Sawosz, F.; Gao, Y.; Ali, A.; et al. Effect of silver nanoparticles on growth performance, metabolism and microbial profile of broiler chickens. Arch. Anim. Nutr. 2012, 66, 416-429. [CrossRef]

42. Elkloub, K.; El Moustafa, M.E.; Ghazalah, A.A.; Rehan, A. Effect of dietary nanosilver on broiler performance. Int. J. Poult. Sci. 2015, 14, 177-182. [CrossRef]

43. Adegbeye, M.J.; Elghandour, M.M.M.Y.; Barbabosa-Pliego, A.; Monroy, J.C.; Mellado, M.; Ravi Kanth Reddy, P.; Salem, A.Z.M. Nanoparticles in Equine Nutrition: Mechanism of Action and Application as Feed Additives. J. Equine Vet. Sci. 2019, 78, 29-37. [CrossRef]

44. Dalloul, R.A.; Lillehoj, H.S. Poultry coccidiosis: Recent advancements in control measures and vaccine development. Expert Rev. Vaccines 2006, 5, 143-163. [CrossRef]

45. Chauke, N.; Siebrits, F.K. Evaluation of silver nanoparticles as a possible coccidiostat in broiler production. S. Afr. J. Anim. Sci. 2012, 42, 493-497. [CrossRef]

46. Gherbawy, Y.A.; Shalaby, I.M.; El-Sadek, M.S.A.; Elhariry, H.M.; Abdelilah, B.A. The anti-fasciolasis properties of silver nanoparticles produced by Trichoderma harzianum and their improvement of the anti-fasciolasis drug triclabendazole. Int. J. Mol. Sci. 2013, 14, 21887-21898. [CrossRef] [PubMed]

47. Izquierdo-Cañas, P.M.; García-Romero, E.; Huertas-Nebreda, B.; Gómez-Alonso, S. Colloidal silver complex as an alternative to sulphur dioxide in winemaking. Food Control 2012, 23, 73-81. [CrossRef]

48. Garde-Cerdán, T.; López, R.; Garijo, P.; González-Arenzana, L.; Gutiérrez, A.R.; López-Alfaro, I.; Santamaría, P. Application of colloidal silver versus sulfur dioxide during vinification and storage of Tempranillo red wines. Aust. J. Grape Wine Res. 2014, 20, 51-61. [CrossRef]

49. García-Ruiz, A.; Crespo, J.; López-de-Luzuriaga, J.M.; Olmos, M.E.; Monge, M.; Rodríguez-Álfaro, M.P.; Martín-Álvarez, P.J.; Bartolome, B.; Moreno-Arribas, M.V. Novel biocompatible silver nanoparticles for controlling the growth of lactic acid bacteria and acetic acid bacteria in wines. Food Control 2015, 50, 613-619. [CrossRef]

50. Carbone, M.; Donia, D.T.; Sabbatella, G.; Antiochia, R. Silver nanoparticles in polymeric matrices for fresh food packaging. J. King Saud Univ. Sci. 2016, 28, 273-279. [CrossRef]

51. Manso, S.; Cacho-Nerin, F.; Becerril, R.; Nerín, C. Combined analytical and microbiological tools to study the effect on Aspergillus flavus of cinnamon essential oil contained in food packaging. Food Control 2013, 30, 370-378. [CrossRef]

52. Medina-Jaramillo, C.; Ochoa-Yepes, O.; Bernal, C.; Famá, L. Active and smart biodegradable packaging based on starch and natural extracts. Carbohydr. Polym. 2017, 176, 187-194. [CrossRef]

53. Moreno, M.A.; Orqueda, M.E.; Gómez-Mascaraque, L.G.; Isla, M.I.; López-Rubio, A. Crosslinked electrospun zein-based food packaging coatings containing bioactive chilto fruit extracts. Food Hydrocoll. 2019, 95, 496-505. [CrossRef]

54. Duncan, T.V. Applications of nanotechnology in food packaging and food safety: Barrier materials, antimicrobials and sensors. J. Colloid Interface Sci. 2011, 363, 1-24. [CrossRef]

55. Tavakoli, H.; Rastegar, H.; Taherian, M.; Samadi, M.; Rostami, H. The effect of nano-silver packaging in increasing the shelf life of nuts: An in vitro model. Ital. J. Food Saf. 2017, 6, 6874. [CrossRef] [PubMed]

56. Inbaraj, B.S.; Chen, B.H. Nanomaterial-based sensors for detection of foodborne bacterial pathogens and toxins as well as pork adulteration in meat products. J. Food Drug Anal. 2016, 24, 15-28. [CrossRef] [PubMed]

57. Abbaspour, A.; Norouz-Sarvestani, F.; Noori, A.; Soltani, N. Aptamer-conjugated silver nanoparticles for electrochemical dual-aptamer-based sandwich detection of staphylococcus aureus. Biosens. Bioelectron. 2015, 68, 149-155. [CrossRef] [PubMed]

58. Roh, S.G.; Robby, A.I.; Phuong, P.T.M.; In, I.; Park, S.Y. Photoluminescence-tunable fluorescent carbon dots-deposited silver nanoparticle for detection and killing of bacteria. Mater. Sci. Eng. C 2019, 97, 613-623. [CrossRef] [PubMed] 
59. Wang, X.; Cui, Q.; Yao, C.; Li, S.; Zhang, P.; Sun, H.; Lv, F.; Liu, L.; Li, L.; Wang, S. Conjugated Polyelectrolyte-Silver Nanostructure Pair for Detection and Killing of Bacteria. Adv. Mater. Technol. 2017, 2, 1700033. [CrossRef]

60. European Food Safety Authority (EFSA). Scientific opinion on the re-evaluation of silver (E 174) as food additive. EFSA J. 2016, 14, 4664.

61. European Food Safety Authority (EFSA). Guidance on risk assessment of the application of nanoscience and nanotechnologies in the food and feed chain: Part 1, human and animal health. EFSA J. 2018, 16, 5327.

62. Ávalos Fúnez, A.; Haza, A.; Morales, P. Nanotecnología en la industria alimentaria I: Aplicaciones. Rev. Complut. Cienc. Vet. 2016, 10, 1-17. [CrossRef]

63. Food and Drug Administration (FDA). Considering Whether an FDA-Regulated Product Involves the Application of Nanotechnology; FDA: Washington, DC, USA, 2014.

64. Richa, S.; Dimple, S.C. Regulatory Approval of Silver Nanoparticles. Appl. Clin. Res. Clin. Trials Regul. Aff. 2018, 5, 74-79.

65. Echegoyen, Y.; Nerín, C. Nanoparticle release from nano-silver antimicrobial food containers. Food Chem. Toxicol. 2013, 62, 16-22. [CrossRef]

66. Cushen, M.; Kerry, J.; Morris, M.; Cruz-Romero, M.; Cummins, E. Evaluation and Simulation of Silver and Copper Nanoparticle Migration from Polyethylene Nanocomposites to Food and an Associated Exposure Assessment. J. Agric. Food Chem. 2014, 62, 1403-1411. [CrossRef] [PubMed]

67. Gallocchio, F.; Cibin, V.; Biancotto, G.; Roccato, A.; Muzzolon, O.; Carmen, L.; Simone, B.; Manodori, L.; Fabrizi, A.; Patuzzi, I.; et al. Testing nano-silver food packaging to evaluate silver migration and food spoilage bacteria on chicken meat. Food Addit. Contam. Part A Chem. Anal. Control Expo. Risk Assess. 2016, 33, 1063-1071. [CrossRef] [PubMed]

68. Mercier-Bonin, M.; Despax, B.; Raynaud, P.; Houdeau, E.; Thomas, M. Mucus and microbiota as emerging players in gut nanotoxicology: The example of dietary silver and titanium dioxide nanoparticles. Crit. Rev. Food Sci. Nutr. 2018, 8, 1023-1032. [CrossRef] [PubMed]

69. Li, J.; Tang, M.; Xue, Y. Review of the effects of silver nanoparticle exposure on gut bacteria. J. Appl. Toxicol. 2019, 39, 27-37. [CrossRef] [PubMed]

70. Walczak, A.P.; Fokkink, R.; Peters, R.; Tromp, P.; Herrera Rivera, Z.E.; Rietjens, I.M.; Hendriksen, P.J.; Bouwmeester, $\mathrm{H}$. Behaviour of silver nanoparticles and silver ions in an in vitro human gastrointestinal digestion model. Nanotoxicology 2013, 7, 1198-1210. [CrossRef]

71. Bouwmeester, H.; van der Zande, M.; Jepson, M.A. Effects of food-borne nanomaterials on gastrointestinal tissues and microbiota. WIREs Nanomed. Nanobiotechnol. 2018, 10, e1481. [CrossRef]

72. Bove, P.; Malvindi, M.A.; Kote, S.S.; Bertorelli, R.; Summa, M.; Sabella, S. Dissolution test for risk assessment of nanoparticles: A pilot study. Nanoscale 2017, 9, 6315-6326. [CrossRef]

73. Gil-Sánchez, I.; Monge, M.; Miralles, B.; Armentia, G.; Cueva, C.; Crespo, J.; de Luzuriaga, J.M.L.; Olmos, M.E.; Bartolomé, B.; de Llano, D.G.; et al. Some new findings on the potential use of biocompatible silver nanoparticles in winemaking. Innov. Food Sci. Emerg. 2019, 51, 64-72. [CrossRef]

74. Cueva, C.; Gil-Sánchez, I.; Ayuda-Durán, B.; González-Manzano, S.; González-Paramás, A.M.; Santos-Buelga, C.; Moreno-Arribas, M. An integrated view of the effects of wine polyphenols and their relevant metabolites on gut and host health. Molecules 2017, 22, 99. [CrossRef]

75. Akter, M.; Sikder, M.T.; Rahman, M.M.; Ullah, A.K.M.A.; Hossain, K.F.B.; Banik, S.; Hosokawa, T.; Saito, T.; Kurasaki, M. A systematic review on silver nanoparticles-induced cytotoxicity: Physicochemical properties and perspectives. J. Adv. Res. 2018, 9, 1-16. [CrossRef]

76. Verkhovskii, R.; Kozlova, A.; Atkin, V.; Kamyshinsky, R.; Shulgina, T.; Nechaeva, O. Physical properties and cytotoxicity of silver nanoparticles under different polymeric stabilizers. Heliyon 2019, 5, e01305. [CrossRef] [PubMed]

77. Fahmy, H.M.; Mosleh, A.M.; Elghany, A.A.; Shams-Eldin, E.; Abu Serea, E.S.; Ali, S.A.; Shalan, A.E. Coated silver nanoparticles: Synthesis, cytotoxicity, and optical properties. RSC Adv. 2019, 9, 20118-20136. [CrossRef]

78. Inkielewicz-Stepniak, I.; Santos-Martinez, M.J.; Medina, C.; Radomski, M.W. Pharmacological and toxicological effects of co-exposure of human gingival fibroblasts to silver nanoparticles and sodium fluoride. Int. J. Nanomed. 2014, 9, 1677-1687. 
79. Niska, K.; Knap, N.; Kedzia, A.; Jaskiewicz, M.; Kamysz, W.; Inkielewicz-Stepniak, I. Capping Agent-Dependent Toxicity and Antimicrobial Activity of Silver Nanoparticles: An In Vitro Study. Concerns about Potential Application in Dental Practice. Int. J. Med. Sci. 2016, 13, 772-782. [CrossRef]

80. Hernandez-Sierra, J.F.; Galicia-Cruz, O.; Angelica, S.A.; Ruiz, F.; Pierdant-Perez, M.; Pozos-Guillen, A.J. In vitro cytotoxicity of silver nanoparticles on human periodontal fibroblasts. J. Clin. Pediatr. Dent. 2011, 36, 37-41. [CrossRef]

81. Tang, X.; Li, L.; Meng, X.; Liu, T.; Hu, Q.; Miao, L. Cytotoxicity of Silver Nanoparticles on Human Periodontal Ligament Fibroblasts. Nanosci. Nanotechnol. Lett. 2017, 9, 1015-1022. [CrossRef]

82. Panpaliya, N.P.; Dahake, P.T.; Kale, Y.J.; Dadpe, M.V.; Kendre, S.B.; Siddiqi, A.G.; Maggavi, U.R. In vitro evaluation of antimicrobial property of silver nanoparticles and chlorhexidine against five different oral pathogenic bacteria. Saudi Dent. J. 2019, 31, 76-83. [CrossRef]

83. Vargas-Reus, M.A.; Memarzadeh, K.; Huang, J.; Ren, G.G.; Allaker, R.P. Antimicrobial activity of nanoparticulate metal oxides against peri-implantitis pathogens. Int. J. Antimicrob. Agents 2012, 40, 135-139. [CrossRef]

84. Lichtenstein, D.; Ebmeyer, J.; Knappe, P.; Juling, S.; Bohmert, L.; Selve, S.; Niemann, B.; Braeuning, A.; Thunemann, A.F.; Lampen, A. Impact of food components during in vitro digestion of silver nanoparticles on cellular uptake and cytotoxicity in intestinal cells. Biol. Chem. 2015, 396, 1255-1264. [CrossRef]

85. Pind'áková, L.; Kašpárková, V.; Kejlová, K.; Dvořáková, M.; Krsek, D.; Jírová, D.; Kašparová, L. Behaviour of silver nanoparticles in simulated saliva and gastrointestinal fluids. Int. J. Pharm. 2017, 527, 12-20. [CrossRef]

86. Gurunathan, S.; Qasim, M.; Park, C.; Yoo, H.; Kim, J.H.; Hong, K. Cytotoxic Potential and Molecular Pathway Analysis of Silver Nanoparticles in Human Colon Cancer Cells HCT116. Int. J. Mol. Sci. 2018, 19, 2269. [CrossRef] [PubMed]

87. Vila, L.; García-Rodríguez, A.; Cortés, C.; Marcos, R.; Hernández, A. Assessing the effects of silver nanoparticles on monolayers of differentiated Caco-2 cells, as a model of intestinal barrier. Food Chem. Toxicol. 2018, 116, 1-10. [CrossRef] [PubMed]

88. Abdelkhaliq, A.; van der Zande, M.; Undas, A.K.; Peters, R.J.B.; Bouwmeester, H. Impact of in vitro digestion on gastrointestinal fate and uptake of silver nanoparticles with different surface modifications. Nanotoxicology 2019, 1-16. [CrossRef] [PubMed]

89. Trickler, W.J.; Lantz, S.M.; Murdock, R.C.; Schrand, A.M.; Robinson, B.L.; Newport, G.D.; Schlager, J.J.; Oldenburg, S.J.; Paule, M.G.; Slikker, W., Jr.; et al. Silver nanoparticle induced blood-brain barrier inflammation and increased permeability in primary rat brain microvessel endothelial cells. Toxicol. Sci. 2010, 118, 160-170. [CrossRef] [PubMed]

90. Çiftçi, H.; Türk, M.; Tamer, U.; Karahan, S.; Menemen, Y. Silver nanoparticles: Cytotoxic, apoptotic, and necrotic effects on MCF-7 cells. Turk. J. Biol. 2013, 37, 573-581. [CrossRef]

91. Jiao, Z.H.; Li, M.; Feng, Y.X.; Shi, J.C.; Zhang, J.; Shao, B. Hormesis effects of silver nanoparticles at non-cytotoxic doses to human hepatoma cells. PLOS ONE 2014, 9, e102564. [CrossRef] [PubMed]

92. Khorrami, S.; Zarrabi, A.; Khaleghi, M.; Danaei, M.; Mozafari, M.R. Selective cytotoxicity of green synthesized silver nanoparticles against the MCF-7 tumor cell line and their enhanced antioxidant and antimicrobial properties. Int. J. Nanomed. 2018, 13, 8013-8024. [CrossRef]

93. Chernousova, S.; Epple, M. Silver as antibacterial agent: Ion, nanoparticle, and metal. Angew. Chem. Int. Ed. 2013, 52, 1636-1653. [CrossRef]

94. Yuan, Y.G.; Zhang, S.; Hwang, J.Y.; Kong, I.K. Silver Nanoparticles Potentiates Cytotoxicity and Apoptotic Potential of Camptothecin in Human Cervical Cancer Cells. Oxid. Med. Cell. Longev. 2018, 2018, 6121328. [CrossRef]

95. Sharma, H.S.; Ali, S.F.; Hussain, S.M.; Schlager, J.J.; Sharma, A. Influence of engineered nanoparticles from metals on the blood-brain barrier permeability, cerebral blood flow, brain edema and neurotoxicity. An experimental study in the rat and mice using biochemical and morphological approaches. J. Nanosci. Nanotechnol. 2009, 9, 5055-5072. [CrossRef]

96. Mwilu, S.K.; El Badawy, A.M.; Bradham, K.; Nelson, C.; Thomas, D.; Scheckel, K.G.; Tolaymat, T.; Ma, L.; Rogers, K.R. Changes in silver nanoparticles exposed to human synthetic stomach fluid: Effects of particle size and surface chemistry. Sci. Total Environ. 2013, 447, 90-98. [CrossRef] [PubMed]

97. Marchioni, M.; Jouneau, P.H.; Chevallet, M.; Michaud-Soret, I.; Deniaud, A. Silver nanoparticle fate in mammals: Bridging in vitro and in vivo studies. Coord. Chem. Rev. 2018, 364, 118-136. [CrossRef] 
98. Cueva, C.; Gil-Sánchez, I.; Tamargo, A.; Miralles, B.; Crespo, J.; Bartolomé, B.; Moreno-Arribas, M.V. Gastrointestinal digestion of food-use silver nanoparticles in the dynamic SIMulator of the GastroIntestinal tract (simgi ${ }^{\circledR}$ ). Impact on human gut microbiota. Food Chem. Toxicol. 2019, 132, 110657. [CrossRef] [PubMed]

99. Das, P.; McDonald, J.; Petrof, E.; Allen-Vercoe, E.; Walker, V. Nanosilver-mediated change in human intestinal microbiota. J. Nanomed. Nanotechnol. 2014, 5, 1.

100. Cattò, C.; Garuglieri, E.; Borruso, L.; Erba, D.; Casiraghi, M.C.; Cappitelli, F.; Villa, F.; Zecchin, S.; Zanchi, R. Impacts of dietary silver nanoparticles and probiotic administration on the microbiota of an in-vitro gut model. Environ. Pollut. 2019, 245, 754-763. [CrossRef] [PubMed]

101. Rahman, M.F.; Wang, J.; Patterson, T.A.; Saini, U.T.; Robinson, B.L.; Newport, G.D.; Murdock, R.C.; Schlager, J.J.; Hussain, S.M.; Ali, S.F. Expression of genes related to oxidative stress in the mouse brain after exposure to silver-25 nanoparticles. Toxicol. Lett. 2009, 187, 15-21. [CrossRef] [PubMed]

102. Jeong, G.N.; Jo, U.B.; Ryu, H.Y.; Kim, Y.S.; Song, K.S.; Yu, I.J. Histochemical study of intestinal mucins after administration of silver nanoparticles in Sprague-Dawley rats. Arch. Toxicol. 2010, 84, 63-69. [CrossRef]

103. Kim, Y.S.; Song, M.Y.; Park, J.D.; Song, K.S.; Ryu, H.R.; Chung, Y.H.; Chang, H.K.; Lee, J.H.; Oh, K.H.; Kelman, B.J.; et al. Subchronic oral toxicity of silver nanoparticles. Part. Fibre Toxicol. 2010, 7, 20. [CrossRef]

104. Shahare, B.; Yashpal, M. Toxic effects of repeated oral exposure of silver nanoparticles on small intestine mucosa of mice. Toxicol. Mech. Method 2013, 23, 161-167. [CrossRef]

105. Skalska, J.; Frontczak-Baniewicz, M.; Strużyńska, L. Synaptic degeneration in rat brain after prolonged oral exposure to silver nanoparticles. NeuroToxicology 2015, 46, 145-154. [CrossRef]

106. Xu, L.; Shao, A.; Zhao, Y.; Wang, Z.; Zhang, C.; Sun, Y.; Deng, J.; Chou, L.L. Neurotoxicity of Silver Nanoparticles in Rat Brain After Intragastric Exposure. J. Nanosci. Nanotechnol. 2015, 15, 4215-4223. [CrossRef]

107. Wilding, L.A.; Bassis, C.M.; Walacavage, K.; Hashway, S.; Leroueil, P.R.; Morishita, M.; Maynard, A.D.; Philbert, M.A.; Bergin, I.L. Repeated dose (28-day) administration of silver nanoparticles of varied size and coating does not significantly alter the indigenous murine gut microbiome. Nanotoxicology 2016, 10, 513-520. [CrossRef] [PubMed]

108. Williams, K.; Milner, J.; Boudreau, M.D.; Gokulan, K.; Cerniglia, C.E.; Khare, S. Effects of subchronic exposure of silver nanoparticles on intestinal microbiota and gut-associated immune responses in the ileum of Sprague-Dawley rats. Nanotoxicology 2015, 9, 279-289. [CrossRef] [PubMed]

109. Hendrickson, O.D.; Klochkov, S.G.; Novikova, O.V.; Bravova, I.M.; Shevtsova, E.F.; Safenkova, I.V.; Zherdev, A.V.; Bachurin, S.O.; Dzantiev, B.B. Toxicity of nanosilver in intragastric studies: Biodistribution and metabolic effects. Toxicol. Lett. 2016, 241, 184-192. [CrossRef] [PubMed]

110. Siczek, K.; Zatorski, H.; Chmielowiec-Korzeniowska, A.; Pulit-Prociak, J.; Smiech, M.; Kordek, R.; Tymczyna, L.; Banach, M.; Fichna, J. Synthesis and evaluation of anti-inflammatory properties of silver nanoparticle suspensions in experimental colitis in mice. Chem. Biol. Drug Des. 2017, 89, 538-547. [CrossRef] [PubMed]

111. van den Brule, S.; Ambroise, J.; Lecloux, H.; Levard, C.; Soulas, R.; de Temmerman, P.; Palmai-Pallag, M.; Marbaix, E.; Lison, D. Dietary silver nanoparticles can disturb the gut microbiota in mice. Part. Fibre Toxicol. 2016, 13, 38. [CrossRef]

112. Bacchetta, C.; Ale, A.; Simoniello, M.F.; Gervasio, S.; Davico, C.; Rossi, A.S.; Desimone, M.F.; Poletta, G.; López, G.; Monserrat, J.M.; et al. Genotoxicity and oxidative stress in fish after a short-term exposure to silver nanoparticles. Ecol. Indic. 2017, 76, 230-239. [CrossRef]

113. Merrifield, D.; Shaw, B.; Harper, G.; Saoud, I.; Davies, S.; Handy, R.; Henry, T. Ingestion of metal-nanoparticle contaminated food disrupts endogenous microbiota in zebrafish (Danio rerio). Environ. Pollut. 2012, 174, 157-163. [CrossRef]

114. Liu, H.; Wang, X.; Wu, Y.; Hou, J.; Zhang, S.; Zhou, N.; Wang, X. Toxicity responses of different organs of zebrafish (Danio rerio) to silver nanoparticles with different particle sizes and surface coatings. Environ. Pollut. 2019, 246, 414-422. [CrossRef]

115. Liu, X.; Dumitrescu, E.; Kumar, A.; Austin, D.; Goia, D.; Wallace, K.N.; Andreescu, S. Differential lethal and sublethal effects in embryonic zebrafish exposed to different sizes of silver nanoparticles. Environ. Pollut. 2019, 248, 627-634. [CrossRef] 
116. Schultz, C.L.; Wamucho, A.; Tsyusko, O.V.; Unrine, J.M.; Crossley, A.; Svendsen, C.; Spurgeon, D.J. Multigenerational exposure to silver ions and silver nanoparticles reveals heightened sensitivity and epigenetic memory in Caenorhabditis elegans. Proc. Biol. Sci. 2016, 283, 20152911. [CrossRef] [PubMed]

117. Yang, Y.; Xu, G.; Xu, S.; Chen, S.; Xu, A.; Wu, L. Effect of ionic strength on bioaccumulation and toxicity of silver nanoparticles in Caenorhabditis elegans. Ecotoxicol. Environ. Saf. 2018, 165, 291-298. [CrossRef] [PubMed]

118. Moon, J.; Kwak, J.I.; An, Y.J. The effects of silver nanomaterial shape and size on toxicity to Caenorhabditis elegans in soil media. Chemosphere 2019, 215, 50-56. [CrossRef] [PubMed]

119. Wamucho, A.; Unrine, J.M.; Kieran, T.J.; Glenn, T.C.; Schultz, C.L.; Farman, M.; Svendsen, C.; Spurgeon, D.J.; Tsyusko, O.V. Genomic mutations after multigenerational exposure of Caenorhabditis elegans to pristine and sulfidized silver nanoparticles. Environ. Pollut. 2019, 254, 113078. [CrossRef]

120. Panacek, A.; Prucek, R.; Safarova, D.; Dittrich, M.; Richtrova, J.; Benickova, K.; Zboril, R.; Kvitek, L. Acute and chronic toxicity effects of silver nanoparticles (NPs) on Drosophila melanogaster. Environ. Sci. Technol. 2011, 45, 4974-4979. [CrossRef]

121. Araj, S.E.A.; Salem, N.M.; Ghabeish, I.H.; Awwad, A.M. Toxicity of Nanoparticles against Drosophila melanogaster (Diptera: Drosophilidae). J. Nanomater. 2015, 2015, 9. [CrossRef]

122. Raj, A.; Shah, P.; Agrawal, N. Dose-dependent effect of silver nanoparticles (AgNPs) on fertility and survival of Drosophila: An in-vivo study. PLoS ONE 2017, 12, e0178051. [CrossRef]

123. Alaraby, M.; Romero, S.; Hernández, A.; Marcos, R. Toxic and Genotoxic Effects of Silver Nanoparticles in Drosophila. Environ. Mol. Mutagen. 2019, 60, 277-285. [CrossRef]

124. Munger, M.A.; Radwanski, P.; Hadlock, G.C.; Stoddard, G.; Shaaban, A.; Falconer, J.; Grainger, D.W.; Deering-Rice, C.E. In vivo human time-exposure study of orally dosed commercial silver nanoparticles. Nanomed. Nanotechnol. Biol. Med. 2014, 10,1-9. [CrossRef]

(C) 2020 by the authors. Licensee MDPI, Basel, Switzerland. This article is an open access article distributed under the terms and conditions of the Creative Commons Attribution (CC BY) license (http://creativecommons.org/licenses/by/4.0/). 